\title{
Long-Lasting Sprouting and Gene Expression Changes Induced by the Monoclonal Antibody IN-1 in the Adult Spinal Cord
}

\author{
Florence M. Bareyre, Brigitte Haudenschild, and Martin E. Schwab \\ Brain Research Institute, Department of Biology, University of Zürich, ETH Zürich, 8057 Zürich, Switzerland
}

Lesion-induced plasticity of the rat corticospinal tract (CST) decreases postnatally, simultaneously with myelin appearance. In adult rats, compensatory sprouting can be induced by the monoclonal antibody (mAb) IN-1 raised against the growth inhibitory protein Nogo-A. In this study, we examined separately the fate of sensory and motor corticospinal fibers after $\mathrm{mAb} I \mathrm{~N}-1$ application. Intact adult rats treated with the $\mathrm{IN}-1$ antibody exhibited an increase of aberrant CST projections, i.e., sensory fibers projecting into the ventral horn and motor fibers projecting dorsally. Unilateral lesion of the CST [pyramidotomy (PTX)] in the presence of $\mathrm{mAb} I \mathrm{~N}-1$ triggered a progressive reorganization of the sprouting of the remaining CST across the midline, with sensory fibers projecting gradually into the denervated dorsal horn and motor fibers projecting into the dener- vated ventral horn. In unilaterally denervated spinal cords, aberrant sprouts were only transient and disappeared by 6 weeks, whereas midline crossing fibers ending in the appropriate target region were stabilized and persisted over the entire study period. Within the spinal cord, IN-1 antibody treatment was associated with upregulation of growth factors (BDNF, VEGF), growth-related proteins (actin, myosin, GAP-43), and transcription factors (STATs), whereas pyramidotomy induced an enhanced expression of guidance molecules (semaphorins and slits) as well as neurotrophic factors (BDNF, IGFs, BMPs). These gene expression changes may contribute to attraction, guidance, and stabilization of sprouting CST fibers.

Key words: corticospinal tract; GAP-43; gene expression; Nogo-A; plasticity; pyramidotomy; sprouting
The pyramidal tract, originating in the sensory and motor cortex, is the only direct cortical pathway to the spinal cord. In cats (Fetz, 1968), primates (Coulter and Jones, 1977; Cheema et al., 1984; Ralston and Ralston, 1985), and hamsters (Kuang and Kalil, 1990), a precise topographic organization of sensory and motor fibers projecting into the dorsal and ventral horn of the cord, respectively, has been described. The rodent corticospinal pathway is also a valuable model for studying injury-induced plasticity and compensatory growth originating either from the injured side of the cord in the form of collateral sprouting of spared axons (Kalil and Reh, 1979; Kalil and Reh, 1982; Bernstein and Stelzner, 1983; Schreyer and Jones, 1983; Bregman et al., 1989; Merline and Kalil, 1990; Weidner et al., 2001) or from sprouting axons of the intact contralateral corticospinal tract (CST) (Hicks and D'Amato, 1970; Whishaw and Kolb, 1988; Z'Graggen et al., 2000). Many of these studies observed that substantial spontaneous anatomical reorganization is restricted to lesions occurring in early postnatal life. During development, the massive downregulation of CNS regenerative and plastic capacities coincides with the appearance of myelin and its associated neurite growth inhibitory proteins (Kapfhammer and Schwab, 1994a,b; Steeves et al., 1994). Among several proteins inhibiting neurite outgrowth in CNS myelin is NI-250 (now Nogo-A) (Caroni and Schwab, 1988a,b; Chen et al., 2000). The monoclonal antibody (mAb)

Received March 19, 2002; revised May 21, 2002; accepted May 29, 2002.

This work was supported by the Swiss National Foundation (Grant 31-63633.00) and the Christopher Reeve Paralysis Foundation (Spinal Cord Consortium, Springfield, NJ). We thank Dr. J. Del Rio and A. Garcia (Salk Institute, La Jolla, CA) for technical support with the Affymetrix gene chip. We also thank Dr. M. Gesemann (University of Zürich) for advice with the RNase Protection Assay. We acknowledge Dr. Raineteau for the guidance provided during this work.

Correspondence should be addressed to Florence Bareyre, Brain Research Institute, University of Zürich and Department of Biology, ETH Zürich, Winterthurerstrasse 190, 8057 Zürich, Switzerland. E-mail: florence.bareyre@access.unizh.ch. Copyright (C) 2002 Society for Neuroscience $0270-6474 / 02 / 227097-14 \$ 15.00 / 0$
IN-1, raised against NI-250, induces regeneration of adult lesioned corticospinal tract (Schnell and Schwab, 1990; Brosamle et al., 2000) and optic nerve fibers (Weibel et al., 1994). The mAb IN-1 also greatly enhances compensatory sprouting in the adult rat: midline crossing corticorubral and corticopontine fibers originating from the intact tract established bilateral projections after unilateral pyramidotomy (PTX) (Z'Graggen et al., 1998), and CST sprouts grew from the unlesioned to the contralateral denervated spinal cord (Thallmair et al., 1998). After bilateral PTX and IN-1 mAb treatment, the number of collaterals from the rubrospinal tract innervating the cervical cord doubled (Raineteau et al., 2001). In all of these cases, IN-1-induced anatomical reorganization was associated with dramatic behavioral improvement. Functional recovery requires precision in the formation and persistence of new neuronal connections; at present, nothing is known about the underlying molecular mechanisms. Thus this study was undertaken to determine the topographic organization of the rat CST, the long-lasting effects of mAb IN-1 treatment on CST fiber sprouting in the absence of, or after a CNS lesion, and the gene expression changes concomitant with the anatomical reorganization.

The present data show that, also in the rat, projections of the sensory and motor cortex terminate precisely within the spinal dorsal and ventral horn, respectively. The mAb IN-1 triggers sprouting of CST fibers in intact rats that is aberrant but transitory. After unilateral PTX, mAb IN-1 induces compensatory sprouting across the midline that is target specific and mostly stable, suggesting lesion-induced CST sprouting and rewiring. The sprouting effect of the IN-1 antibody was associated with increased growth-related protein expression (among others), whereas the PTX-driven compensatory reorganization was paralleled by enhanced expression of certain guidance molecules. 


\section{MATERIALS AND METHODS}

Male adult Lewis rats (200-220 gm) were used in this study. Anatomical and histochemical data were obtained from 120 animals with successful labeling of the corticospinal axons, and gene expression data were obtained from 30 animals.

\section{Anatomical organization and reorganization of CST projections}

Pyramidotomy and antibody application. Rats were anesthetized using a combination of Hypnorm ( $0.3 \mathrm{mg} / \mathrm{kg}$, s.c; Roche, Basel, Switzerland) and Dormicum $(0.6 \mathrm{mg} / \mathrm{kg}$, s.c.; Roche). A right unilateral lesion of the CST at the level of the medulla oblongata was performed by using a ventral approach (Thallmair et al., 1998). Briefly, the right medullary pyramid was exposed through an opening of the occipital bone, and the right CST was transected rostral to the decussation with the basilar artery serving as a landmark for the midline. At the time of surgery, $4 \mu \mathrm{l}$ of hybridoma cell suspension $\left(10^{5}\right.$ cells) secreting either the monoclonal antibody IN-1 or an anti-HRP as control antibody (Schnell and Schwab, 1993) was injected into the right hippocampal formation (coordinates: $-4 \mathrm{~mm}$ caudal, $5 \mathrm{~mm}$ lateral to bregma, $5 \mathrm{~mm}$ depth). Cyclosporin A $(5 \mathrm{mg} / \mathrm{kg}$ body weight, i.p.; Sandimmun, Novartis, Basel, Switzerland) was given daily during the first $5 \mathrm{~d}$ postoperatively to allow the transplant to grow and secrete the antibody. Pyramidotomized animals receiving no cells were also generated as a control baseline as well as intact animals without pyramidotomy but with antibody transplant only. After surgery, all animals were kept on a heating plate $\left(38^{\circ} \mathrm{C}\right)$ until fully awake and received Carpofen (Rimadyl, $5 \mathrm{mg} / \mathrm{kg}$, i.m.; Pfizer, Karlsruhe, Germany) for $2 \mathrm{~d}$.

Anterograde tracing of the sensory and motor CST. Locations of forelimb sensory and motor cortices were determined by measuring positions on the skull relative to bregma (Neafsey et al., 1986). Pressure injections of $600 \mathrm{nl}$ of a $10 \%$ solution of biotinylated dextran amine [BDA 10,000, Molecular Probes (Eugene, OR) in $0.01 \mathrm{M}$ phosphate buffer, $\mathrm{pH}$ 7.4] were made into either the left forelimb sensory cortex (coordinates: $0.5 \mathrm{~mm}$ posterior to bregma, $4.5 \mathrm{~mm}$ lateral to bregma, $1.5 \mathrm{~mm}$ depth) or the left motor cortex (coordinates: $2 \mathrm{~mm}$ anterior to bregma, $3 \mathrm{~mm}$ lateral to bregma, $1.5 \mathrm{~mm}$ depth) through a glass capillary that remained in its position for 2 min after the end of the injection.

To determine (1) the topographic specificity of corticospinal projections, unlesioned BDA-labeled rats were killed 2 weeks after injection. To determine (2) the temporal reorganization of corticospinal projections after $\mathrm{mAb}$ IN-1 administration, animals were killed 1 week, 2 weeks, and 6 weeks after pyramidotomy and hybridoma implantation. Sham-operated animals (laminectomy at the level of the medulla oblongata only) were also generated and served as a baseline. At the time animals were killed, animals were deeply anesthetized with pentobarbital (450 mg/kg, i.p.; Abbott Laboratories, Cham, Switzerland) and perfused transcardially with $100 \mathrm{ml}$ of Ringer's solution containing 100,000 IU/1 heparin (Liquemin, Roche, Basel, Switzerland) and $0.25 \% \mathrm{NaNO}_{2}$ followed by $300 \mathrm{ml}$ of $4 \%$ paraformaldehyde in $0.1 \mathrm{M}$ phosphate buffer with $5 \%$ sucrose. The brains and spinal cords were dissected and postfixed overnight at $4^{\circ} \mathrm{C}$ in the same fixative. Meninges were removed, and the cervical enlargement was embedded in a gelatin-chicken albumin solution polymerized with $2.5 \%$ glutaraldehyde. Fifty micrometer sections were cut in the coronal plane using a Vibratome (Leica vt 1000S). All sections were collected in $50 \mathrm{~mm}$ Tris-buffered $0.9 \%$ saline, $\mathrm{pH} 8$, and $0.5 \%$ Triton X-100 (TBS-Tx). They were serially mounted on Superfrost slides (Superfrost/Plus, Menzel-Gläser, Germany) according to the semifree floating technique (Herzog and Brosamle, 1997). Sections were washed three times for $30 \mathrm{~min}$ in TBS-Tx before overnight incubation in avidin-peroxidase in TBS-Tx (ABC elite, Vector Laboratories, Burlingame, CA). The next day, the slides were washed three times for $30 \mathrm{~min}$ in TBS-Tx. After an additional wash in $50 \mathrm{~mm}$ Tris-HCl, $\mathrm{pH} 8$, a preincubation for $10 \mathrm{~min}$ in $0.4 \%$ ammonium nickel sulfate (Sigma, St. Louis, MO) was performed, followed by a second preincubation in $0.4 \%$ ammonium nickel sulfate and $0.015 \%$ 3,3'-diaminobenzidine (DAB; Sigma, Buchs, Switzerland) for $10 \mathrm{~min}$. The tissue was then reacted in $0.4 \%$ ammonium nickel sulfate, $0.015 \%$ DAB, and $0.004 \% \mathrm{H}_{2} \mathrm{O}_{2}$ in 50 mM Tris buffer, $\mathrm{pH} \mathrm{8}$, for another $10 \mathrm{~min}$. The process was stopped by washing with Tris- $\mathrm{HCl}$ buffer. The sections were air dried, counterstained slightly with cresyl violet, and coverslipped with Eukitt (Kindler, Freiburg, Germany).

Quantification of anatomical reorganization. Sensory and motor corticospinal projections were quantified by counting (1) the number of sensory axons sprouting across Rexed's lamina $V$ into the ventral horn or the number of motor axons sprouting across Rexed's lamina V into the dorsal horn and (2) the number of axons conserving their topographic location but sprouting across the midline. Quantification was performed by a blinded observer with respect to the treatment and the injury status. Fibers seen physically crossing the midline were counted using a light microscope at $200 \times$ magnification on 40 consecutive sections starting at the standard level C4 (cervical level 4). Quantification of the total number of fibers labeled in the main CST was also performed under light microscopy at $400 \times$ magnification in three separate sections to generate a ratio of sprouting fibers for each animal to account for differences in BDA labeling between individual rats.

Quantification of fiber arborizations. Arborization of the fibers was estimated by scoring as follows: 0 , no sprouts coming out of the fibers; 1 , very few branches per fibers (less than two); 2, branching important but present in $<50 \%$ of the fibers in the anatomical region; 3 , branching important and present in $>50 \%$ of the fibers; 4 , dense branching present in all fibers.

\section{Gene expression changes after IN-1 treatment and pyramidotomy}

Pyramidotomy and antibody application. A first group of rats underwent a right-side pyramidotomy as described above. Sham animals with a laminectomy only were generated in parallel. A second group of rats received hybridoma cells secreting either the mAb IN-1 or the anti-HRP control antibody as described above (no lesion). Control animals receiving no cells were generated in parallel as a baseline. A third group of rats were pyramidotomized, and hybridoma secreting either IN-1 or antiHRP antibodies were implanted. At $48 \mathrm{hr}, 1$ week, or 4 weeks after injury ( $n=3$ per group) rats were decapitated, and the spinal cords were quickly dissected on a cold plate. Three millimeter transverse sections were taken at the cervical enlargement, and for the lesion experiments, the lesioned side was separated from the unlesioned side. Samples of three rats per group were pooled, and the tissue was immediately frozen in isopentane $\left(-70^{\circ} \mathrm{C}\right)$ and subsequently used for RNA extraction.

Sample preparation and hybridization to oligonucleotide arrays. The procedures described in detail in the Affymetrix GeneChip Expression Analysis Manual (Affymetrix Inc., Santa Clara, CA) were followed. RNA was extracted with TRIzol Total RNA Isolation Reagent (Invitrogen, Rockville, MD), and the RNA purity was checked by spectrophotometry and agarose gel electrophoresis. RNA was cleaned (RNEasy Mini Kit, Qiagen Inc., Valencia, CA) and converted to double-stranded cDNA using an oligo dT primer containing the T7 promoter (Invitrogen Superscript Choice System, Invitrogen). The cDNA was cleaned with phase-lock gel, extracted by phenol/chloroform, ethanol precipitated, and used for biotinylated cRNA preparation (Bioarray High Yield RNA Transcription Labeling Kit, Enzo Diagnostics, Farmingdale, NY). The biotinylated cRNA was cleaned (RNEasy spin columns, Quiagen), quantified, fragmented, and checked by agarose gel electrophoresis. Biotinlabeled cRNA was then hybridized to Affymetrix rat genome U34A GeneChip in Affymetrix fluidics station 400. The chips were washed and stained with streptavidin-phycoerythrin.

Data analysis. The oligonucleotide gene chip used in the present study contains several probe sets specific for rat housekeeping genes $(\beta$-actin, GADPH, hexokinase, 5S rRNA) which served as internal controls. Several human, murine, and yeast probe sets on each chip served as negative controls, and externally spiked bacterial bioB, bioC, bioD, and Cre served as positive hybridization controls. The gene chips were scanned with a probe array scanner, and the results were subsequently analyzed using the Affymetrix GeneChip analysis followed by the DNA-Chip Analyzer (dChip) software from Harvard University (Li and Wong, 2001). The Affymetrix GeneChip software conducted the pairwise comparisons among replicate samples. For each treatment group, samples were run in replicate and cross compared, thus generating four pairwise comparisons analyzed with dChip. Fold changes were taken into account only for those genes showing a "fold change" value superior to 1.2 and a $p$ value $<0.05$.

\section{Validation of the gene chip data: RNase protection assay}

The same total RNA extracted previously from spinal cords of IN-1 or anti-HRP-treated rats or control rats for the gene chip analysis was used.

Cloning of rat STAT1, GAP43, vimentin, neurofilament light, and TIMP1 PCR probes. The rat cDNA sequences of STAT1, GAP43, vimentin, neurofilament light (NFL), and TIMP1 were analyzed by using the program Oligo (Primer Analysis Software, Cascade, CO) with regard to their suitability for primer selection. The following primers were used and synthesized (Microsynth, Balgach, Switzerland): GAP43, sense: 5'CAG CCA CCA GCC CTA AGG-3', antisense: 5'-TCA GTG ACA 
GCA GCA GGC-3'; STAT1, sense: 5'-CCA TCC GCT TCC ATG ACC-3', antisense: 5'-GTT TCT GGT CGC TCT TCG-3'; vimentin,

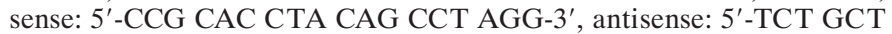
GCT CGA GGA AGC-3'; TIMP1, sense: 5'-AGC TTC CTG GTT CCC TGG-3', antisense: 5'-GGT AGC CCT TCT CAG AGC-3'; NFL, sense: 5'-TCG ACC TCC TAC AAG CGG-3', antisense: 5'-ACC AAC AGC TCG GCT TCC - $3^{\prime}$. Riboprobes were transcribed from linearized templates prepared in Bluescript plasmid using the $\mathrm{T} 7$ in vitro transcription system (Stratagene) and labeled with ${ }^{32} \mathrm{P}$ uridine triphosphate.

Isolation and analysis of RNA. Ribonuclease protection assays were performed using the Ribo Quant Kit (PharMingen). For each reaction, probes $\left(4.610^{5} \mathrm{cpm}\right)$ were hybridized against $10 \mu \mathrm{g}$ of spinal cord RNA and RNase-treated according to the manufacturer's instructions. tRNA was used as negative control. GAPDH was used as an internal standard for the amount and integrity of the RNA preparations. Protected fragments were separated on a $5 \%$ sequencing gel. Radioactivity in each band was quantified using a PhosphorImager (Amersham Biosciences). The level of expression of each RNA was calculated as a ratio of the protected RNA fragment to the intensity of the protected GAPDH fragment. The intensity of the GAPDH fragment was roughly equivalent in all the samples, showing that GAPDH expression was independent of any treatment applied. Relative expression values (fold changes) were calculated by dividing the level in antibody-treated rats by the level in control untreated rats. Experiments were performed three to six times.

\section{GAP-43 immunohistochemical staining and analysis}

Spinal cord sections were collected and mounted as explained previously. Primary antibodies were used at dilution of 1:1000 (GAP-43, Chemicon) and 1:40 (vimentin, Chemicon). Immunohistochemistry for each antibody was performed on all sections at the same time. Sections were incubated in methanol containing $5 \% \mathrm{H}_{2} \mathrm{O}_{2}$ to quench endogenous peroxidases, washed in $0.1 \mathrm{M}$ Tris buffer, $\mathrm{pH} 7.4$, and blocked in TBS-T $\times$ $5 \%$ normal horse serum. All antibodies were diluted in TBS-T $\times 5 \%$ normal horse serum and AB complex in $0.1 \mathrm{M}$ Tris buffer. Sections were incubated overnight with primary antibody at $4^{\circ} \mathrm{C}$ and incubated at room temperature for $1 \mathrm{hr}$ with appropriate biotinylated secondary antibodies [biotin-SP donkey anti-rabbit IgG (Jackson ImmunoResearch; West Grove, PA; dilution, 1:1000) for polyclonal GAP-43; biotin-SP rabbit anti-goat IgG (Vector Laboratories; dilution, 1:300) for vimentin]. Sections were then incubated at room temperature for $1 \mathrm{hr}$ with $\mathrm{AB}$ reagent (Vector Laboratories) and developed with 3,3'-diaminobenzidine (Sigma). Sections were dehydrated and coverslipped. Application of control serum instead of primary antibody on selected sections of rat tissue provided a negative control. Intensity of the stainings was quantified by trained personnel blinded to treatment and injury status of the animals. Under low-power light microscopy, an image of the whole cervical cord was captured by video camera, and the borders of the spinal cord were traced manually. The pixels per area were then automatically calculated using an image analysis software routine (MCID/M4, Imaging Research, St. Catherines, Ontario, Canada) after defining a threshold for the background that was kept identical throughout the analysis. A ratio between animals treated with IN-1 and anti-HRP antibodies was then calculated.

\section{Statistical evaluation}

All data were analyzed using a nonparametric Kruskall-Wallis test in cases of multiple comparisons followed by nonparametric Mann-Whitney tests in cases of paired comparisons. Significance was taken at $p<$ 0.05 and indicated with an asterisk.

\section{RESULTS}

\section{Specific topographic organization of sensory and motor corticospinal projections in normal rats}

Both forelimb sensory and motor cortex give rise to corticospinal axons that reach their target in the gray matter of the cervical enlargement. Most of the corticospinal fibers cross in the pyramidal decussation and enter the ventral region of the dorsal columns (O'Leary and Koester, 1993). When the injection site of BDA was confined to either the sensory or the motor cortex, the corticospinal projections were located in the dorsal horn (laminas II-V) (Fig. $1 A$ ) or to the ventral horn (laminas V-X) (Fig. 1B), respectively, demonstrating a clear topographic organization of corticospinal arbors with a small overlap in lamina V. Sensory projections in the dorsal horn were much denser than motor projections in the ventral horn and were mainly concentrated in laminas III-V. Projections from the motor cortex terminated most heavily in laminas VI-IX. Motor corticospinal axons were found to arborize and ramify widely to reach the motoneuronal pool. A small ipsilateral ventral component $(<5 \%)$ was also observed as described previously (Armand, 1982; Joosten et al., 1992; Brosamle and Schwab, 1997).

\section{Sprouting of corticospinal fibers after monoclonal antibody IN-1 administration in intact adult animals}

Animals sustaining a laminectomy without lesion of the pyramid were implanted with either IN-1 or anti-HRP antibody secreting cells, and sensory or motor corticospinal projections in the cervical enlargement were analyzed by comparison to control rats receiving no cells. Quantification of sprouting fibers was conducted 2 weeks after antibody application in two ways: (1) fibers topographically projecting across the midline and (2) fibers aberrantly sprouting across lamina $\mathrm{V}$ (i.e., motor fibers entering laminas III and IV and sensory fibers entering laminas VI and VII). When BDA was injected into the sensory cortex, no midline-crossing fibers could be detected in any of the treatment groups. In particular, animals implanted with anti-HRP or IN-1 antibodies were not statistically different $(p>0.05)$ from control animals (Fig. 2A). Similarly, when BDA was injected into the motor cortex, no midline-crossing fibers were observed after anti-HRP antibody treatment $(p>0.05)$ (Fig. $2 B)$. However, the number of midline-crossing fibers was slightly higher after IN-1 monoclonal antibody treatment ( $p<0.05$; IN-1 antibody-treated rats vs anti-HRP antibody-treated rats or control rats) (Fig. 2B).

When invasion of the ventral horn by sensory fibers was evaluated, no statistical differences were seen between anti-HRP antibody-treated rats and control rats. Conversely, IN-1 antibodytreated rats demonstrated significantly more sensory fibers entering the ventral horn than anti-HRP antibody-treated rats and control rats ( $p<0.05$ and $p<0.01$, respectively (Figs. $2 A, 3 A, B$ ). When motor CST fibers were observed for their ability to invade the dorsal horn, anti-HRP and IN-1 antibody-treated animals showed significantly more ectopic fibers than control animals ( $p<0.05$ in both cases) (Fig. $2 B$ ). In addition, IN-1 antibodytreated animals demonstrated a significantly higher $(p<0.05)$ (Figs. $2 B, 3 C, D)$ number of motor CST fibers invading the dorsal horn than anti-HRP antibody-treated animals. These observations show that monoclonal antibody IN-1 induces sprouting of sensory and motor CST fibers in the noninjured adult rat spinal cord.

\section{Long-term topographic reorganization of adult corticospinal fibers after pyramidotomy and implantation of monoclonal antibody IN-1 secreting cells}

The CST was removed unilaterally by transection at the entry into the pyramidal decussation (pyramidotomy). Reorganization of the fibers was assessed 1,2, and 6 weeks after pyramidotomy in rats implanted with IN-1 or anti-HRP antibody-secreting cells or in control rats (lesion only). As previously, quantification of the sprouting fibers was conducted by counting (1) fibers topographically projecting across the midline and (2) fibers aberrantly sprouting into the inappropriate horn (i.e., motor fibers entering laminas III and IV and sensory fibers entering laminas VI and VII). Because we counted only fibers visibly crossing the midline, we did not include ipsilateral ventral fibers that were also reported 

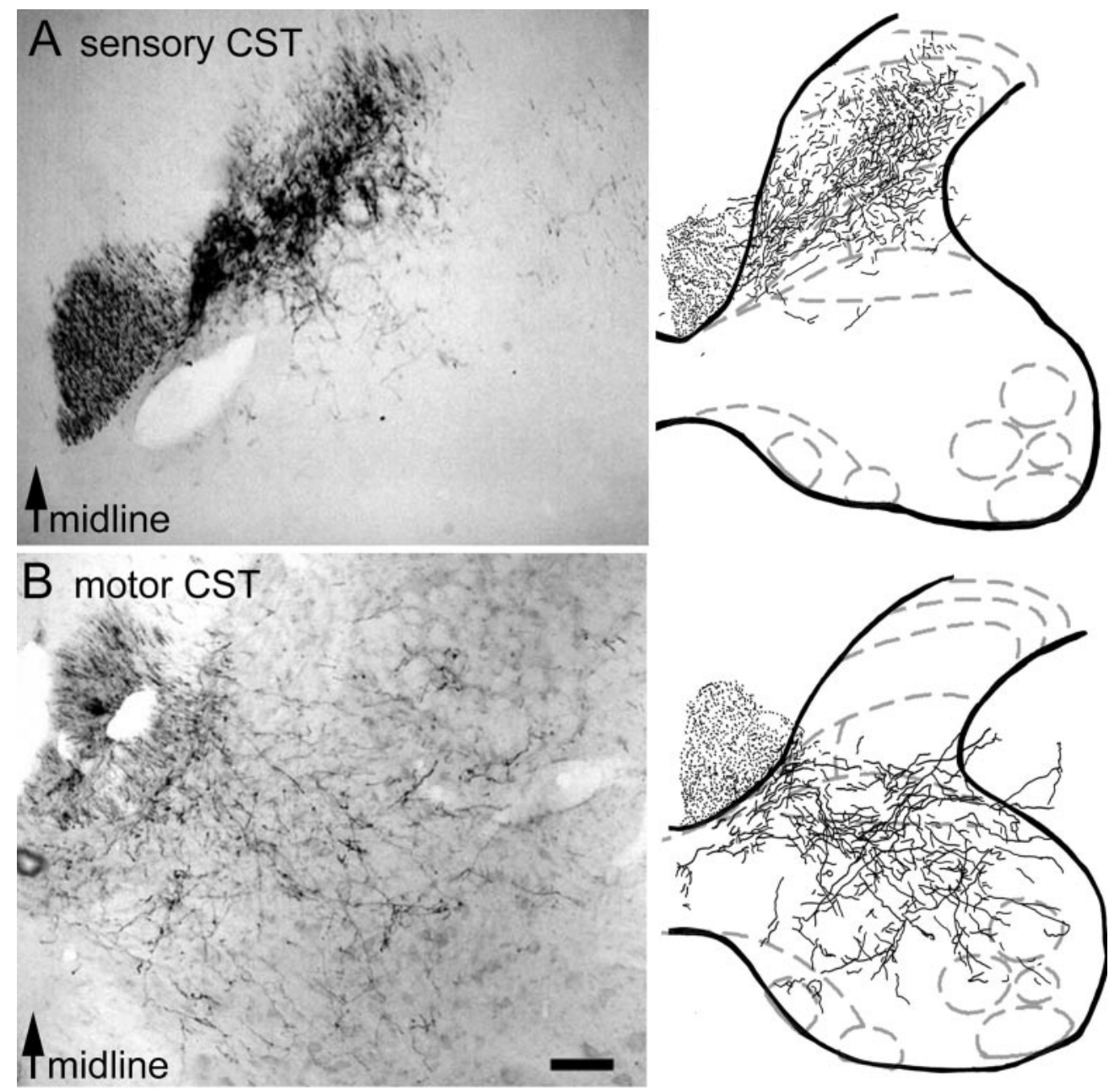

Figure 1. Photomicrographs and camera lucida reconstructions of corticospinal projections to the cervical spinal cord. $A$, Projections of sensory CST fibers to the dorsal horn as shown by injections of BDA into the sensory cortex. $B$, Projections of motor CST fibers to the intermediate layers and the ventral horn as shown by injections of BDA into the motor cortex. Scale bar, $250 \mu \mathrm{m}$.

by Weidner et al. (2001) to sprout after a CST lesion. In all sprouting parameters examined (i.e., aberrant or across the midline), no significant sprouting of motor or sensory fibers was observed 1 week after pyramidotomy when anti-HRP antibodytreated rats were compared with control rats (Fig. 4A-D). Conversely, IN-1 antibody-treated rats demonstrated significantly more motor and sensory fibers crossing the midline at 1 week (Fig. $4 B, D$ ) when compared with control and anti-HRP antibodytreated rats ( $p<0.05$ in both cases). IN-1 antibody-treated rats also showed significantly more ectopic motor and sensory fibers invading the dorsal and ventral horns, respectively, by comparison with control rats $(p<0.05)$ but not anti-HRP antibody-treated rats 1 week after pyramidotomy (Fig. $4 A, C$ ).

At 2 weeks after injury, anti-HRP antibody-treated animals showed an increased number of sprouting fibers when compared with control animals in all parameters examined $(p<0.05$ in all cases) except for ectopic sensory CST projections. IN-1 antibodytreated animals showed significantly more midline crossing fibers than control animals in all parameters examined $(p<0.05$ in all cases) (Fig. 4). In addition, IN-1 antibody-treated rats exhibited significantly more sensory and motor fibers topographically crossing the midline to invade the contralateral dorsal and ventral horn, respectively, than anti-HRP antibody-treated animals $(p<$ 0.01 ) (Fig. $5 A-D)$. When aberrant sprouting of sensory fibers (into the ventral horn) was considered, a small but statistical increase was also shown after IN-1 antibody treatment when compared with anti-HRP antibody treatment 2 weeks after pyramidotomy.

At 6 weeks after injury, animals treated with anti-HRP antibody were similar to control animals in all parameters examined. Conversely, IN-1 antibody-treated animals exhibited a significantly higher sprouting index when compared with control animals $(p<0.05)$ in all cases. In addition, IN-1 antibody-treated animals exhibited significantly more motor fibers topographically crossing the midline than anti-HRP antibody-treated animals $(p<0.01)$, indicating that the sprouts triggered by the antibody IN-1 at 1 or 2 weeks after the lesion were stable over an extended period of time.

\section{Motor corticospinal fibers persist over time and arborize}

We estimated the arborization complexity of motor CST fibers grown across the midline into the denervated ventral horn by a 0-4 point score ( 0 , no branches/4, highly branched terminal arbors) at 1,2, and 6 weeks after pyramidotomy and anti-HRP or IN-1 antibody application. We observed that at 1 and 2 weeks, scores were low, and the branching complexity after IN-1 treatment was not statistically different from the complexity of the rare fibers seen after anti-HRP treatment. Conversely, 6 weeks after the injury, a significantly higher arborization complexity was detected in IN-1 antibody-treated animals when compared with the very few fibers seen after anti-HRP treatment $(p<0.05)$ (Fig. 

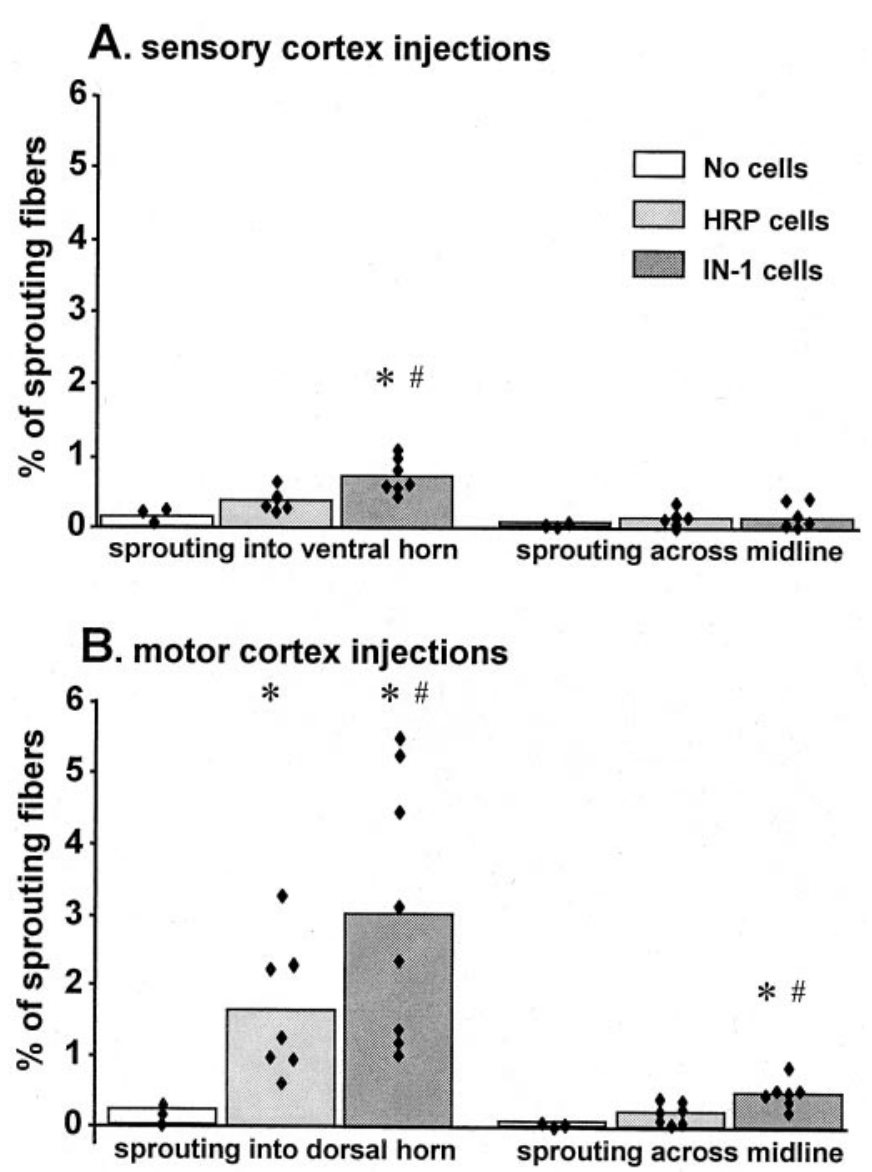

Figure 2. Percentage of CST fibers sprouting across lamina V or across the midline in the cervical spinal cord in nonlesioned animals. $A$, Sensory CST projections. $B$, Motor CST projections. Monoclonal antibody IN-1 induced both sensory and motor fibers to sprout across lamina $\mathrm{V}$ when compared with anti-HRP mAb treatment. In addition, IN-1 induced motor fibers to cross the midline of the spinal cord. ${ }^{*}$ IN-1 or HRP antibody-treated rats significantly different from control non-treated rats $(p<0.05)$. \#IN-1 antibody-treated animals significantly different from anti-HRP antibody-treated rats $(p<0.05)$. Black diamonds indicate individual values.

$6)$, indicating that the persisting fibers acquired a more pronounced complexity (Fig. 6A,B).

\section{Gene expression changes in the cervical spinal cord after pyramidotomy and $\mathrm{IN}-1$ monoclonal antibody application}

Of 8784 oligonucleotide probe sets present on the Affymetrix U34A chips, 3601-4589 (41-52\%) were identified as present in control as well as in injured or antibody-treated rats. Replicate chips, done for each experimental point, gave extremely similar results ( $R^{2}$ above 0.95 after paired comparison analysis).

\section{Gene expressions changes in the cervical spinal cord after pyramidotomy: $48 \mathrm{hr}$ and 1 week}

In the denervated cervical spinal cord, at $48 \mathrm{hr}$ after pyramidotomy, the major upregulated genes were IGFII, IGF receptor, and binding protein, BMP-2, components of the pro-apoptotic cascade (BAD/caspases/c-jun), some extracellular matrix (ECM) proteins (laminin/decorin/collagen), and enzymes of the cell metabolism (Table 1). Some metabolic genes were also downregulated (lipooxygenase/acyl-coA synthase). At 1 week after pyramidotomy, we found prominent upregulation of growth factors and their receptors (trkB/VEGF receptor/BDNF), the axonal guidance molecules (semaphorin 3/slit1), and ECM proteins (decorin/lumican/collagens). Cytoskeletal proteins (actin/myo$\sin / \mathrm{MAP} 2), \mathrm{GABA}$ receptors, and several ion transporters $\left(\mathrm{Cl}^{-} /\right.$ $\mathrm{HCO}_{3}^{-}$exchanger/NaK ATPase/Ca ${ }^{2+}$ ATPase) were downregulated (Table 1).

Gene expressions altered in the cervical spinal cord after monoclonal antibody IN-1 treatment: $48 \mathrm{hr}$ and 1 week

In the cervical spinal cord, at $48 \mathrm{hr}$, when unlesioned animals treated with IN-1 were compared with animals treated with anti-HRP antibody, the major upregulated genes were for cytoskeletal proteins (actin/myosin), creatin kinase, and calciumbinding proteins, genes related to inflammation and collagens (Table 2). At 1 week, when animals treated with monoclonal antibody IN-1 were compared with animals treated with antiHRP antibody, cytoskeletal proteins (actin/myosin/troponin), the growth-associated protein GAP-43, and the growth factors (BDNF/VEGF) were upregulated several-fold as were transcription factors (STAT1/MRP14), the SNARE protein VAMP1, synapsin3a, creatine kinase, the inhibitor of metalloproteinases TIMP1, and collagens (Table 2). The major downregulated genes were related to immune functions and components of the complement system (Table 2).

Genes altered in the cervical spinal cord after pyramidotomy and IN-1 or anti-HRP antibody treatment: 1 and 4 weeks

At 1 week, when the denervated spinal cord of animals treated with monoclonal antibody IN-1 were compared with the denervated spinal cord of animals treated with anti-HRP antibody, the major upregulated genes were cytoskeletal proteins (MAP2/actin), the growth-associated protein GAP-43, growth factors/receptors (BDNF/TrkB/IGFI and II/GDNF receptor/glia maturation factor/ endothelin receptor), semaphorin $3 \mathrm{a}, \mathrm{ECM}$, and membrane proteins (NCAM/F3/APP/collagen/laminin/TIMP1), and transcription factors (STATs) (Table 3). The major downregulated genes were immune response-related molecules such as MHC Class II and components of the complement system (Table 3). At 4 weeks, when the denervated spinal cord of animals treated with monoclonal antibody IN-1 were compared with the denervated spinal cord of animals treated with anti-HRP antibody, only very few gene expression changes were observed. The major upregulated gene was BDNF. Actin and collagen were downregulated (Table 3).

\section{RNase protection assays}

RNase protection assays confirmed the increased expression of GAP-43, TIMP1, and STAT1 and the unaltered expression of NFL and vimentin in rats treated for $7 \mathrm{~d}$ with mAb IN-1 compared with anti-HRP antibody (Fig. 7). The magnitude of the changes between control antibody and $\mathrm{IN}-1$ antibody-treated rats were in the same range as those found with the gene chip technology for most of the studied genes.

\section{Immunoreactivity of GAP-43 after pyramidotomy and IN-1 and anti-HRP antibody treatments}

We quantified the immunoreactivity of the growth-related protein GAP-43 and of vimentin in the cervical cord after IN-1 or anti-HRP treatments in unlesioned rats and in rats 1,2 , and 6 weeks after pyramidotomy. IN-1 antibody-treated animals exhibited a twofold increase in GAP-43 immunoreactivity in unlesioned animals as well as 1 and 2 weeks after the lesion and IN-1 antibody treatment when compared with their matching controls (Fig. 8). No differences in GAP-43 immunoreactivity were found 
Figure 3. Photomicrographs of fibers sprouting across lamina $\mathrm{V}$ in nonlesioned animals. $A$, No invasion of the ventral horn by sensory fibers after anti-HRP treatment. $B$, Invasion of the ventral horn by sensory fibers (arrows) after IN-1 treatment. $C$, No invasion of the dorsal horn by motor fibers after anti-HRP treatment. $D$, Pronounced invasion of the dorsal horn by motor fibers (arrows) after IN-1 treatment. Scale bar, $250 \mu \mathrm{m}$
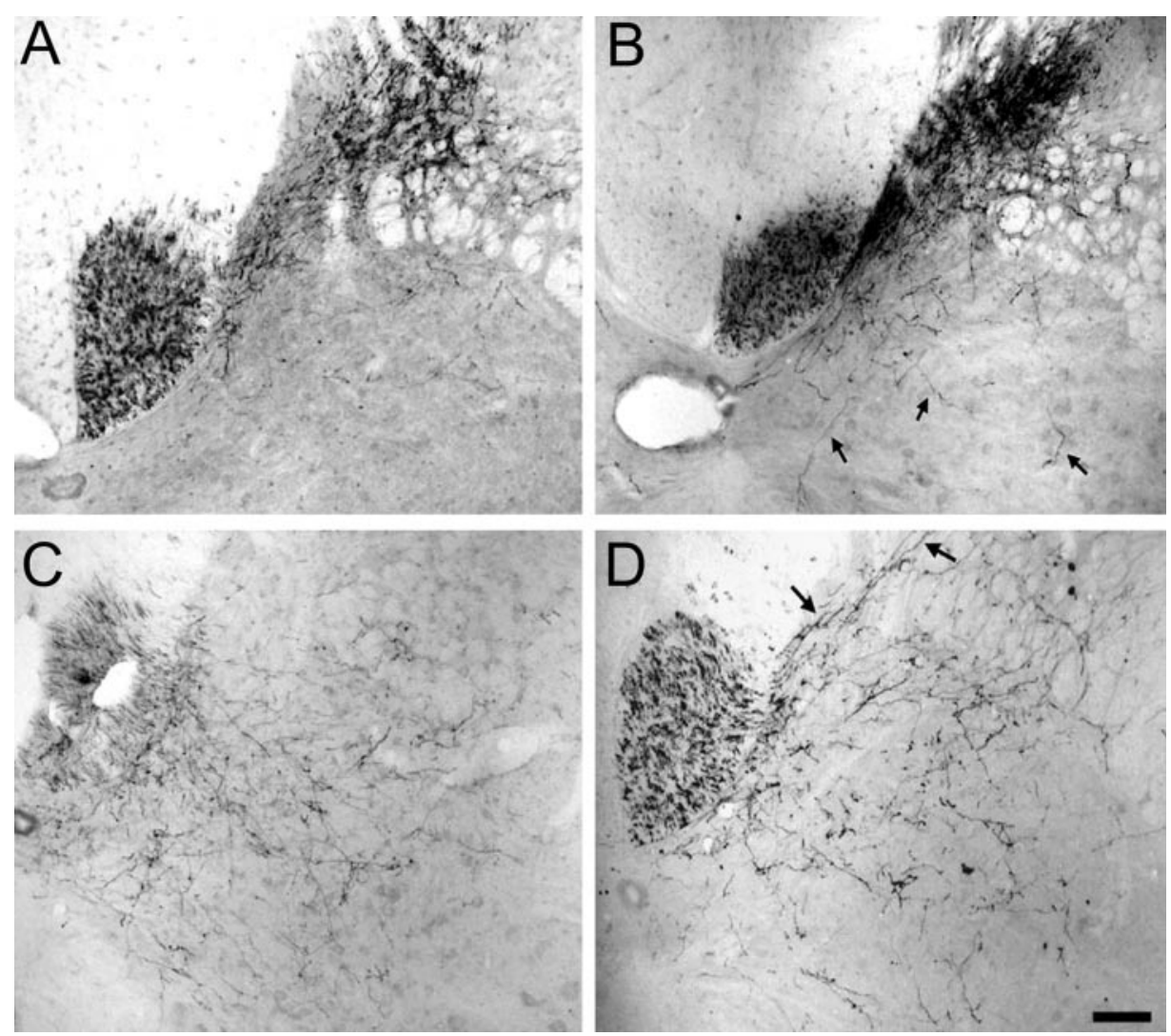

6 weeks after the lesion when IN-1 antibody-treated animals were compared with anti-HRP animals. Vimentin immunoreactivity was unchanged for the entire study period when IN-1 antibodytreated animals were compared with anti-HRP antibody-treated animals.

\section{DISCUSSION}

The present results show that the monoclonal antibody IN-1 induces transitory sprouting of CST fibers in the normal adult rat spinal cord associated with enhanced gene expression in particular of cytoskeletal and growth-related proteins and transcription factors. The IN-1 antibody combined with a discrete unilateral pyramidal tract lesion further enhanced the sprouting, especially of motor CST fibers, which formed stable, highly branched projections in the denervated ventral horn. This reorganization was associated with an upregulation of genes such as growth factors/ receptors and guidance molecules.

\section{The corticospinal tract is topographically organized}

Electrophysiological mapping of the rat sensorimotor cortex has shown a clear topographic organization of somatosensory and motor areas (Donoghue and Wise, 1982; Neafsey et al., 1986), despite regions of overlap of both forelimb and hindlimb representations. Anatomically, the somatosensory and motor cortices can be distinguished in several species by the fact that their corticospinal arbors project differentially within the gray matter of the spinal cord. In the cat, monkey, and opossum (Cheema et al., 1984; Ralston and Ralston, 1985), axons from somatosensory cortex terminate primarily in the dorsal horn, whereas corticospinal axons from the motor cortex terminate most heavily within the ventral horn on interneurons and also on motoneurons (Liu and Rouiller, 1999). The present study demonstrates that also in adult rats, somatosensory and motor cortex are clearly separated anatomically, as reflected by their spinal projections. Contradicting earlier anatomical data for adult rats (Jones et al., 1982; Schreyer and Jones, 1982; Bernstein and Stelzner, 1983; Casale et al., 1988) and hamster (Reh and Kalil, 1981) done with less sensitive tracers and showing that CST fibers terminate most heavily in the medial region of the dorsal horn, more sparsely in the intermediate zone, and not at all in the immediate vicinity of the motoneurons, our present observations are in agreement with the data of Wise and Donoghue (1986) and Liu and Rouiller (1999) showing extensive projections from the motor cortex to intermediate layers of the spinal cord and the region of the motoneuronal pools. Similarly, in hamsters, Kuang and Kalil (1990) demonstrated that somatosensory cortical projections were located in the dorsal horn in the medial half of laminas III, IV, and $\mathrm{V}$ and that motor CST projections were located in the ventral horn extending up to the pool of motoneurons.

\section{The monoclonal antibody IN-1 enhances sprouting in normal adult spinal cord}

The monoclonal antibody IN-1, raised against the growth inhibitory protein Nogo-A (Caroni and Schwab, 1988a; Spillmann et al., 1998; Chen et al., 2000), is able to selectively and significantly enhance sprouting of sensory and motor corticospinal fibers in normal rat spinal cord. We verified the ability of the hybridoma to secrete large amounts of antibody in vivo by measuring the IN-1 antibody titers in the blood; they were found in all animals tested to be $\sim 6 \mu \mathrm{g} / \mathrm{ml} 1$ week after cell implantation. It could also be possible that, by binding to myelin, the antibody initiates a complement-mediated injury to oligodendroglia. We confirmed that no damages attributable to inflammatory processes were observed by performing immunohistochemical stainings for macrophages (OX42) and microglia (ED1). Using similar IN-1 hybridoma grafts or IN-1 Fab pumps, evidence of IN-1-induced 


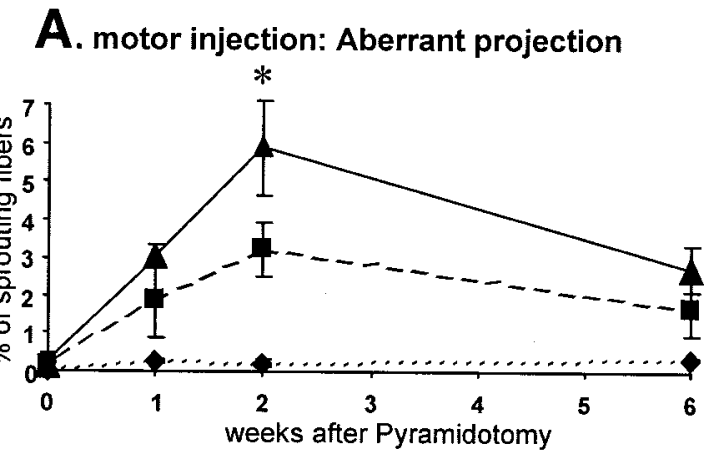

B. motor injection: Midline crossing fibers

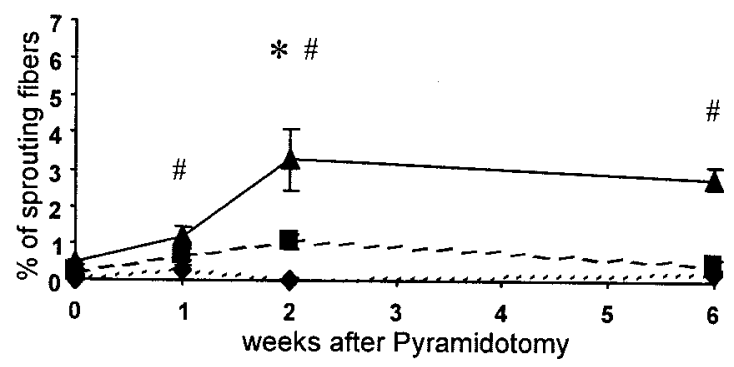

C. sensory injection: Aberrant projection

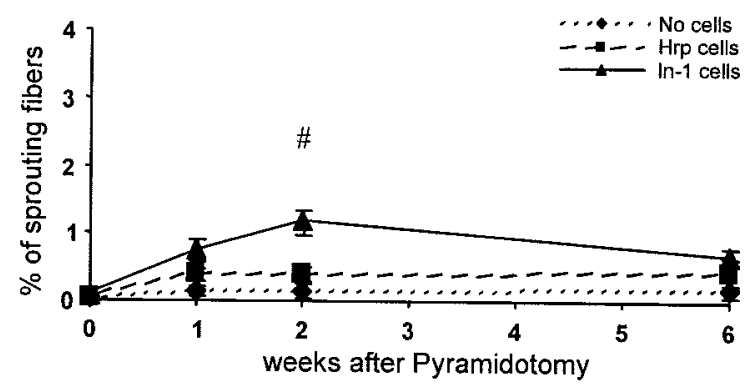

D. sensory injection: Midline crossing fibers

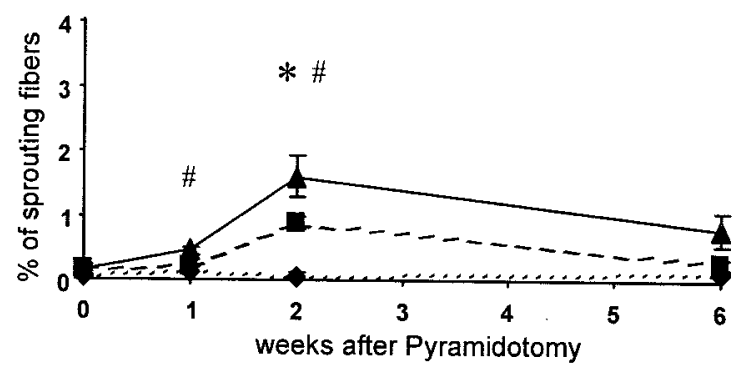

Figure 4. Long-term reorganization of motor $(A, B)$ or sensory $(C, D)$ CST fibers in pyramidotomized animals. IN-1 treatment induced more motor fibers to sprout dorsally $(A)$ and more sensory fibers to invade the ventral horn on the intact side 2 weeks after pyramidal tract lesion than anti-HRP antibody treatment $(C)$. IN-1 also induced motor and sensory fibers to cross the midline 1 and 2 weeks after pyramidal tract lesion, in contrast to anti-HRP treatment $(B, D)$. Sensory sprouts retracted, but motor fibers grew across the midline to the denervated cord and were stable at 6 weeks after injury $(B)$. *Anti-HRP-treated rats significantly different from control nontreated rats $(p<0.05)$. \#IN-1 antibody-treated rats significantly different from anti-HRP-treated rats $(p<0.05)$.
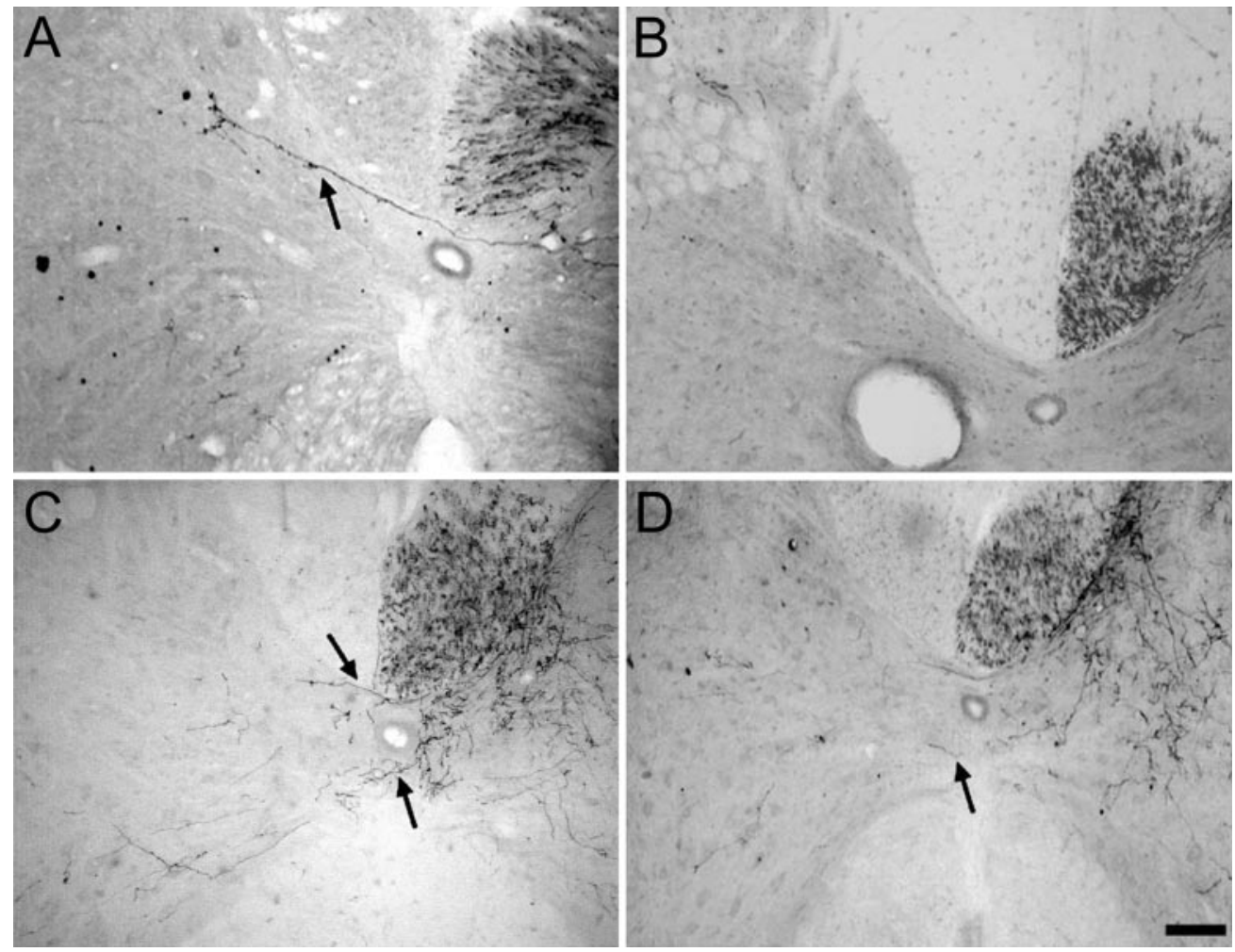

Figure 5. Photomicrographs of fibers sprouting across the spinal cord midline 2 weeks after pyramidotomy. $A$, Topographic sprouting of a sensory CST fiber (arrow) into the contralateral, denervated dorsal horn after IN-1 mAb treatment. $B$, Absence of sprouting of sensory fibers after anti-HRP treatment. $C$, Topographic sprouting of motor CST fibers into the contralateral ventral horn (arrows) after IN-1 mAb treatment. $D$, Virtual absence of sprouting (very rare fibers) of motor fibers in anti-HRP treatment. Scale bar, $250 \mu \mathrm{m}$. 

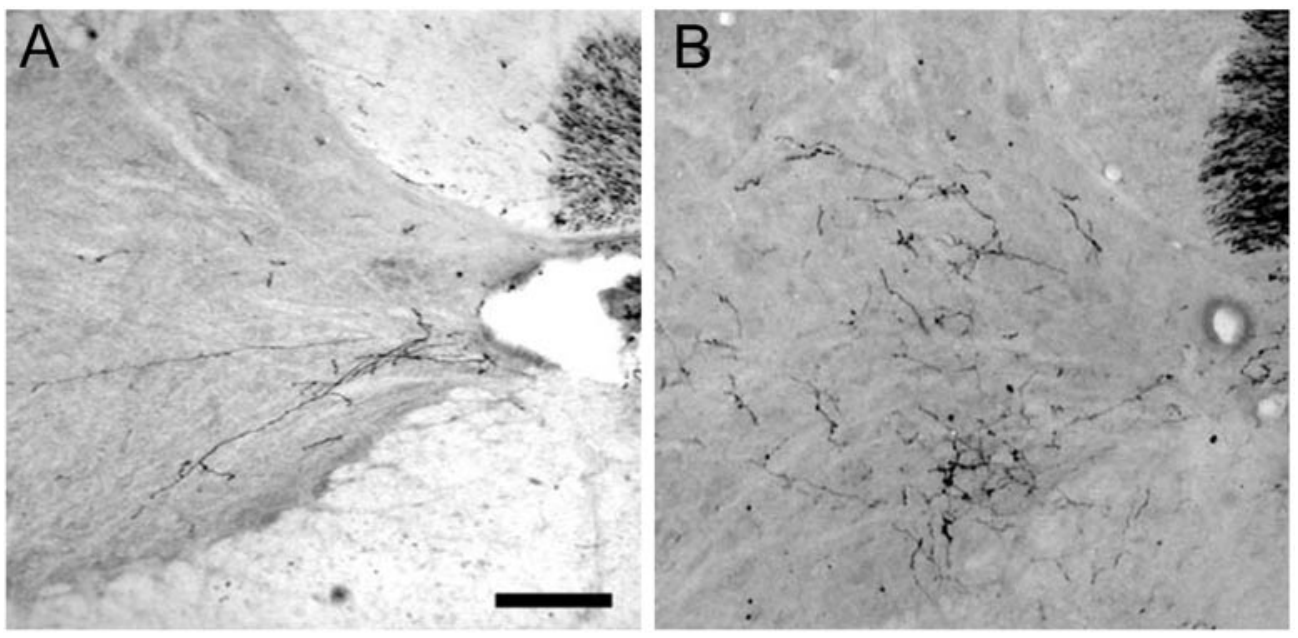

Figure 6. Photomicrographs of the arbor complexity of motor fibers grown across the midline into the denervated ventral horn at 2 weeks $(A)$ and 6 weeks $(B)$ after pyramidotomy and monoclonal IN-1 antibody treatment. $C$, Complexity of axonal arbors of motor CST fibers 1,2 , and 6 weeks after pyramidotomy and antibody treatment. Six weeks after the injury, IN-1-treated animals had higher scores than anti-HRPtreated animals. Scores are described in Materials and Methods. *IN-1-treated rats significantly different from antiHRP-treated rats $(p<0.05)$. Black and white diamonds represent individual values. Scale bar, $200 \mu \mathrm{m}$.
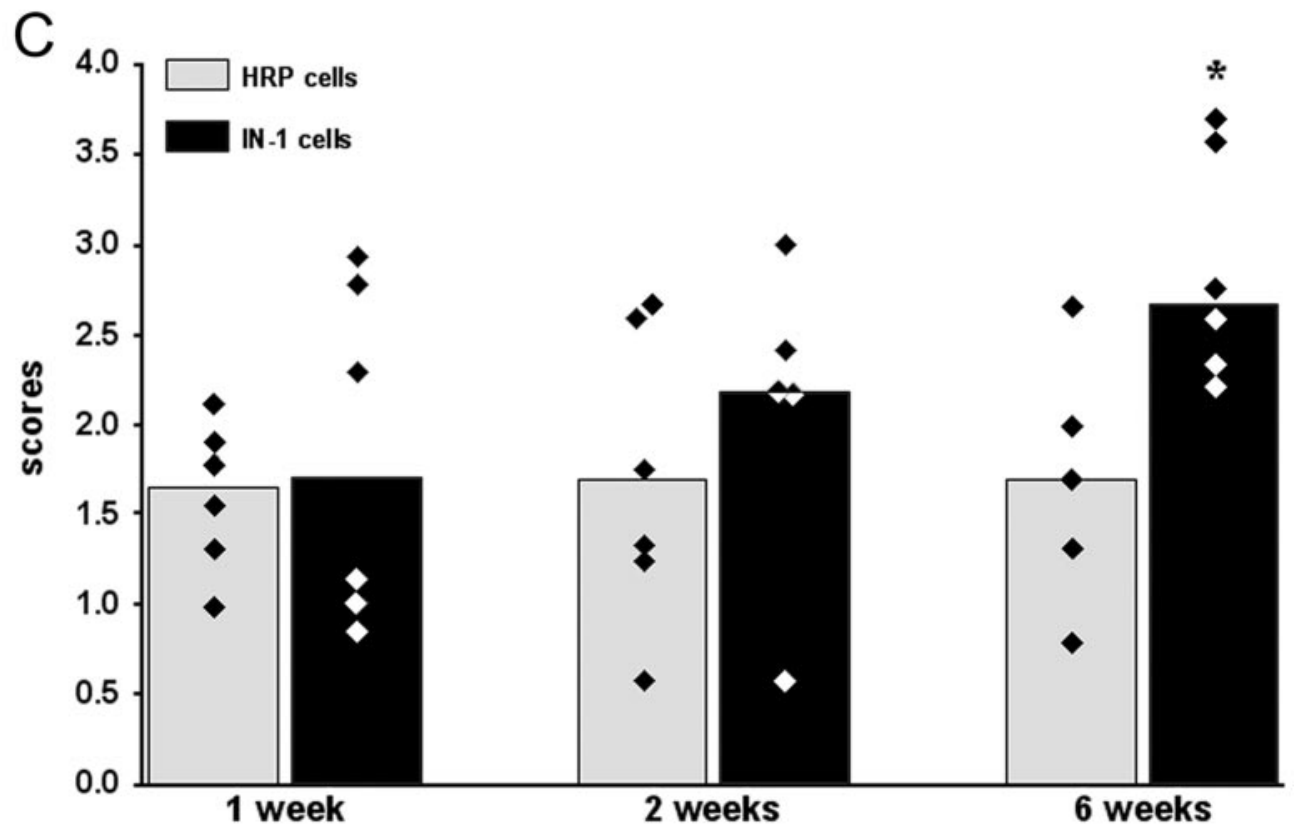

axon regrowth and compensatory sprouting was obtained in spinal cord- or brainstem-lesioned animals (Schnell and Schwab, 1990; Schwab and Bartholdi, 1996; Thallmair et al., 1998; Z'Graggen et al., 1998; Raineteau et al., 1999, 2001; Brosamle et al., 2000). Buffo et al. (2000) then demonstrated that in intact animals, a single injection of IN-1 antibody Fab fragment or of an antiserum against Nogo-A was able to induce aberrant profuse but transitory sprouting of Purkinje axons in the granular layer of the cerebellum with a concomitant upregulation of specific growth-associated markers (Zagrebelsky et al., 1998). Here we observe that in the spinal cord, IN-1-induced sprouting of intact CST axons typically displays sensory fibers growing into the ventral horn and motor fibers projecting dorsally and slightly across the midline. However, the presence of these ectopic and aberrant fibers did not seem to impair the gross behavior of the animals. With respect to the mode of action of the IN-1 antibody, interesting hints were provided by the Affymetrix gene chip analysis. Hence, GAP-43 mRNA and protein levels were upregulated in unlesioned IN-1 antibody-treated animals compared with unlesioned anti-HRP antibody-treated rats or untreated controls. Klein et al. (1999) showed that enhanced expression of GAP-43 by somatic gene transfer was associated with axonal sprouting and the formation of aberrant terminal clusters in the nigrostriatal and septohippocampal pathways. IN-1 administration was also associated with the upregulation within the spinal cord environment (intrinsic spinal neurons and glial cells) of transcription factors such as STAT1 and to a lesser extent STAT3. Several reports have shown that the STAT family of transcription factors was expressed after peripheral but not central axotomy and therefore could play a role in signal transduction and regulation of gene activity during peripheral nerve regeneration (Rajan et al., 1995; Yao et al., 1997; Schwaiger et al., 2000). We hypothesize that the mAb IN-1, raised against the growth inhibitor Nogo-A, leads to the activation of the growth program of adult CNS neurons as reflected by an increased transcription of genes such as STATs, GAP-43, actin, and myosin and by sprouting of axons.

\section{The mAb IN-1 enhances long-term compensatory sprouting after unilateral lesion of the pyramidal tract}

After unilateral pyramidotomy in adult rats and subsequent treatment with the mAb IN-1, sprouting of the remaining, intact corticospinal tract has previously been observed (Thallmair et al., 
Table 1. Differential gene expression in the cervical cord when the denervated side was compared with the intact side of the cervical spinal cord (3-mm-thick sections; three rats pooled) $48 \mathrm{hr}$ and 1 week after pyramidotomy

\begin{tabular}{|c|c|c|c|}
\hline Probe set & Gene & $\begin{array}{l}\text { Fold change } \\
48 \mathrm{hr}\end{array}$ & $\begin{array}{l}\text { Fold change } \\
1 \text { week }\end{array}$ \\
\hline \multicolumn{4}{|l|}{ Cell metabolism } \\
\hline M27886 & Bifunctional enzyme 6-phosphofructo-2-kinase/fructose 2,6-bisphosphatase & 2.84 & \\
\hline rc_AI012589_s_at & Glutathione $S$-transferase, pi 2 & 1.42 & \\
\hline J02592_s_at & Glutathione $S$-transferase, mu type $2(\mathrm{Yb} 2)$ & & 1.39 \\
\hline $\mathrm{J} 03867 \mathrm{~s}$ at & NADH-cytochrome b-5 reductase & & -1.47 \\
\hline M11670_at & Catalase & & -1.63 \\
\hline AB00255﹎_at & Glycerol 3-phosphate dehydrogenase & & -1.52 \\
\hline D85189 & Acyl-CoA synthetase & -2.31 & \\
\hline S69383 & 12-lipoxygenase & -3.53 & \\
\hline AA800851 & pl 6.1 esterase & -3.59 & \\
\hline L06040 & 12-lipoxygenase & -4.30 & \\
\hline \multicolumn{4}{|l|}{ Cytoskeletal proteins } \\
\hline J00692_at & $\alpha$-actin & & -2.93 \\
\hline S68736_at & Myosin heavy chain & & -3.03 \\
\hline L00088expanded_cds\#2_at & Fast myosin alkali light chain & & -3.04 \\
\hline X53455 & Microtubule-associated protein 2 & & -4.31 \\
\hline \multicolumn{4}{|l|}{ Extracellular matrix proteins } \\
\hline X84039 & Lumican & & 4.03 \\
\hline M21354 & Collagen type III alpha-1 & 2.11 & 3.17 \\
\hline $\mathrm{X} 70369 \mathrm{~s}$ at & Pro $\alpha 1$ collagen type III & & 2.67 \\
\hline Z78279_at & Collagen $\alpha 1$ type $\mathrm{I}$ & & 2.18 \\
\hline rc_AI639233_s_at & Decorin & 2.02 & \\
\hline Z12298cds_s_at & Dermatan sulfate proteoglycan-II (decorin) & 1.99 & 2.14 \\
\hline U75405UTR\#1_f_at & $\alpha 1$ type I collagen & 1.47 & \\
\hline \multicolumn{4}{|l|}{$\begin{array}{l}\text { Growth factors/receptors/ } \\
\text { guidance molecules }\end{array}$} \\
\hline M55293 & Neural receptor protein-tyrosine kinase (trkB) & & 25.71 \\
\hline X95286 & Semaphorin III/collapsin-1 & & 3.22 \\
\hline U93306 & VEGF receptor-2/FLK-1 & & 3.14 \\
\hline S76758 & BDNF & & 2.22 \\
\hline M91595exon_s_at & Insulin-like growth factor binding protein-2 & 2.03 & \\
\hline X17012mRNA_s_at & IGFII gene for insulin-like growth factor II & 1.85 & \\
\hline L20678_at & Bone morphogenetic protein 2 & 1.85 & \\
\hline AB017170 & Slit-1 protein & & 1.81 \\
\hline M15481_g_at & Insulin-like growth factor I (IGF-I) & 1.79 & \\
\hline U25650_f_at & Low-affinity NGF receptor precursor & & 1.56 \\
\hline AB016160_g_at & GABAB receptor $1 \mathrm{c}$ & & -1.44 \\
\hline AF058795_at & GABA-B receptor gb2 & & -1.64 \\
\hline \multicolumn{4}{|l|}{ Immunological proteins } \\
\hline $\mathrm{K} 02815 \mathrm{~s}$ at & MHC RT1-B region class II (Ia antigen) A- $\alpha$ glycoprotein & & 1.49 \\
\hline \multicolumn{4}{|l|}{ Intracellular cell signaling } \\
\hline AF003523 & BAD & 2.86 & \\
\hline AF072124 & Caspase 7 & 2.85 & -2.70 \\
\hline AF025671 & Caspase 2 & 2.13 & \\
\hline $\mathrm{X} 17163$ & $\mathrm{c}-j u n$ oncogene for transcription factor AP-1 & 2.02 & -2.81 \\
\hline M24104_at & Vesicle-associated membrane protein (synaptobrevin 2) & 1.83 & \\
\hline M24104_g at & Vesicle-associated membrane protein (synaptobrevin 2) & 1.67 & \\
\hline AB003991 at & SNAP-25A & & -1.47 \\
\hline S74122 & bcl- $2=$ proto-oncogene & & -3.2 \\
\hline \multicolumn{4}{|l|}{ Ion transport } \\
\hline AF004017_at & Electrogenic $\mathrm{Na}^{+}$bicarbonate cotransporter & & -1.46 \\
\hline J05166 & $3 \mathrm{Cl}-/ \mathrm{HCO}_{3}$-exchanger (B3RP2) & & -1.81 \\
\hline D90049 & $\mathrm{Na}^{+}, \mathrm{K}^{+}$-ATPase (EC 3.6.1.3) $\alpha 2$ subunit gene & & -2.45 \\
\hline M99223 & Calcium transporting ATPase & & -3.02 \\
\hline \multicolumn{4}{|l|}{ Schwann cell proteins } \\
\hline Z29649_at & Periaxin & 1.96 & 2.76 \\
\hline S55427_s_at & Myelin protein SR13=growth-arrest-specific Gas-3 homolog & 1.77 & 1.76 \\
\hline \multicolumn{4}{|c|}{ 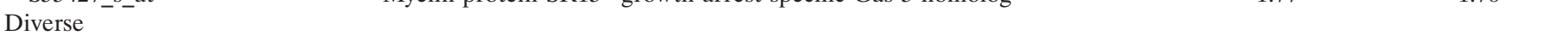 } \\
\hline X07266 & Gene 33 polypeptide & & -4.10 \\
\hline X59864 & ASM15 & & -8.33 \\
\hline rc_AI231445_at & RNA binding protein & & -1.63 \\
\hline
\end{tabular}

Data are presented as fold changes. Only significant changes $(>1.2$-fold; $p<0.05)$ using dChip are presented. 


\begin{tabular}{|c|c|c|c|}
\hline Probe set & Gene & $\begin{array}{l}\text { Fold change } \\
48 \mathrm{hr}\end{array}$ & $\begin{array}{l}\text { Fold change } \\
1 \text { week }\end{array}$ \\
\hline \multicolumn{4}{|l|}{ Cell metabolism } \\
\hline M18668_at & Brain creatine kinase & 3.10 & 41.90 \\
\hline M99223_at & Calcium transporting ATPase & -3.09 & 5.77 \\
\hline rc_AA900582_at & $\alpha$-2-macroglobulin & & -1.53 \\
\hline M23566exon_s_at & $\alpha$-2-macroglobulin & & -1.73 \\
\hline rc_AA817854_s_at & Mitochondrial cytochrome B & & -2.10 \\
\hline \multicolumn{4}{|l|}{ Cytoskeletal proteins } \\
\hline J00692_at & $\alpha$-actin & 3.62 & 32.97 \\
\hline S68736_at & Myosin heavy chain & 3.26 & 11.02 \\
\hline L00088expanded_cds\#2_at & Fast myosin alkali light chain & 4.19 & 7.91 \\
\hline M73701_at & Troponin I & -5.26 & 5.51 \\
\hline X02412_at & Tropomyosin 3, alpha & -1.58 & \\
\hline \multicolumn{4}{|l|}{ Extracellular matrix proteins } \\
\hline Z78279_at & Collagen $\alpha 1$ type I & 2.68 & 6.92 \\
\hline Z78279_g_at & Collagen $\alpha 1$ type I & 2.37 & 5.53 \\
\hline rc_AI231472_s_at & Procollagen $\alpha 1$ type I & 2.17 & 3.36 \\
\hline Z12298cds_s_at & Dermatan sulfate proteoglycan-II (decorin) & -1.28 & \\
\hline rc_AI179399_at & Collagen type $\mathrm{V}, \alpha 2$ & -1.33 & \\
\hline \multicolumn{4}{|l|}{ Growth factors/receptors } \\
\hline S76799_at & BDNF & & 1.90 \\
\hline L20913_s_at & VEGF & & 1.80 \\
\hline \multicolumn{4}{|l|}{ Growth-related proteins } \\
\hline L21192_at & GAP-43 & & 1.91 \\
\hline \multicolumn{4}{|l|}{ Immunological proteins } \\
\hline U50353mRNA_s_at & Neutrophil defensin $3 a$ & 1.79 & 10.11 \\
\hline U16686_at & Defensin 1 precursor & 1.92 & 3.31 \\
\hline M15562_g_at & MHC class II RT1.u-D- $\alpha$ chain & & -1.63 \\
\hline K02815_s_at & MHC RT1-B region class II & & -1.69 \\
\hline X52477_at & Complement component 3 & & -1.69 \\
\hline X14254cds_g_at & MHC class II-associated invariant chain & & -1.72 \\
\hline M29866_s_at & Complement component $\mathrm{C} 3$ & & -1.73 \\
\hline M15562_at & MHC class II RT1.u-D- $\alpha$ chain & & -1.75 \\
\hline X13044_at & CD74 antigen (invariant polypeptide of MHC II antigen-associated) & & -1.76 \\
\hline U68272_at & Interferon $\gamma$ receptor & & -2.00 \\
\hline X56596_at & MHC class II antigen RT1.B- $\beta$-chain & & -2.02 \\
\hline X71127_g_at & Complement protein $\mathrm{C} 1 \mathrm{q} \beta$ chain & & -2.03 \\
\hline \multicolumn{4}{|l|}{ Intracellular cell signaling } \\
\hline rc_AA892553_at & STAT 1 & & 7.11 \\
\hline L18948_at & Intracellular calcium-binding protein (MRP14) & 2.49 & 4.42 \\
\hline AF056704_at & Synapsin $3 a$ & & 2.40 \\
\hline M24104_g_at & VAMP-1 (synaptobrevin2) & & 1.83 \\
\hline \multicolumn{4}{|l|}{ Diverse } \\
\hline X59864mRNA_g_at & ASM15 gene & 3.50 & 12.74 \\
\hline rc_AI169327_g_at & TIMP 1 (tissue inhibitor of metalloproteinase 1) & & 5.12 \\
\hline rc_AA957003_at & S100 calcium-binding protein A8 (calgranulin A) & 2.56 & \\
\hline rc_AA925246_at & Cathepsin $\mathrm{K}$ & -2.11 & \\
\hline M25490_at & Bone $\gamma$-carboxyglutamic acid (Gla) protein (osteocalcin) & -2.21 & 5.94 \\
\hline rc_AI639532_at & Calmodulin & -2.59 & \\
\hline Y07704_g_at & Hypothetical protein & & 2.08 \\
\hline AA944073_at & Ribosomal protein L41 & & -1.26 \\
\hline X58389cds_s_at & Ribosomal protein L17 & & -1.30 \\
\hline X58465mRNA_at & Ribosomal protein S5 & & -1.35 \\
\hline X78327_at & Ribosomal protein L13 & & -1.36 \\
\hline X93352_at & Ribosomal protein L10a & & -1.36 \\
\hline X62322_g_at & Granulin & & -1.49 \\
\hline X52733cds_s_at & Ribosomal protein $\mathrm{L} 27 \mathrm{a}$ & & -1.51 \\
\hline
\end{tabular}


Table 3. Non-exhaustive differential gene expression in the cervical cord 1 week and 4 weeks after both pyramidotomy and IN-1 or anti-HRP antibody application

\begin{tabular}{|c|c|c|c|}
\hline Probe set & Gene & $\begin{array}{l}\text { Fold change } \\
1 \text { week }\end{array}$ & $\begin{array}{l}\text { Fold change } \\
4 \text { weeks }\end{array}$ \\
\hline \multicolumn{4}{|l|}{ Cell adhesion molecules } \\
\hline D38492_at & Neural adhesion molecule F3 & 1.90 & \\
\hline rc_AI137246_s_at & NCAM & 1.84 & \\
\hline M14656_at & Sialoprotein (osteopontin) & -1.43 & \\
\hline D00913_g_at & Intercellular adhesion molecule-1 & -1.58 & \\
\hline \multicolumn{4}{|l|}{ Cell metabolism } \\
\hline D10770_s_at & $\beta$ isoform of catalytic subunit of cAMP-dependent protein kinase & 2.65 & \\
\hline X13983mRNA_at & $\alpha$-2-macroglobulin gene exon 1 (and joined CDS) & 1.72 & \\
\hline L05557cds_at & Plasma membrane calcium ATPase isoform 2 & 1.71 & \\
\hline D00636cds_s_at & NADH-cytochrome b5 reductase & 1.59 & \\
\hline U75932_at & Protein kinase, cAMP dependent, regulatory, type 1 & 1.35 & \\
\hline X55298_at & Ribophorin II & -1.35 & \\
\hline \multicolumn{4}{|l|}{ Cytoskeletal protein } \\
\hline X53455cds_s_at & Microtubule-associated protein 2 & 7.71 & \\
\hline rc_AA900769_s_at & $\alpha$ actin & 4.72 & -1.54 \\
\hline X16623cds_s_at & Neuraxin & 2.79 & \\
\hline X77934cds_at & Amyloid precursor-like protein 2 & 2.06 & \\
\hline rc_AI029183_s_at & Gap junction protein, $\alpha 1,43$ kD (connexin 43 ) & 2.06 & \\
\hline U35775_at & $\gamma$-adducin & 1.56 & \\
\hline X05834_at & Fibronectin & -2.03 & \\
\hline rc_AA892506_at & Coronin/actin binding protein & -2.21 & \\
\hline rc_AA892333_at & $\alpha$-tubulin & -3.28 & \\
\hline \multicolumn{4}{|c|}{ Extracellular matrix proteins } \\
\hline U75405UTR\#1_f_at & $\alpha 1$ type I collagen & 1.56 & -1.61 \\
\hline X94551_at & Laminin $\gamma 1$ & 1.35 & \\
\hline rc_AI231472_s_at & Procollagen type $1 \alpha 1$ & 1.34 & -1.39 \\
\hline L14851_at & Neurexin III- $\alpha$ & -1.33 & \\
\hline S61868_at & Ryudocan =heparan sulfate proteoglycan core protein & -1.41 & \\
\hline X67788_at & Ezrin & -1.61 & \\
\hline \multicolumn{4}{|l|}{ Growth factors/receptors } \\
\hline rc_AA818970_s_at & Endothelin receptor & 3.97 & \\
\hline M55293 & Neural receptor protein-tyrosine kinase (trkB) & 2.81 & \\
\hline S76799_at & BDNF & 2.68 & 2.13 \\
\hline Z11558_at & Glia maturation factor $\beta$ & 2.55 & \\
\hline X57514_at & $\mathrm{GABA}(\mathrm{A})$ receptor $\gamma-1$ & 2.36 & \\
\hline M15481_g_at & Insulin-like growth factor I (IGF-I) & 1.77 & \\
\hline AF003825_s_at & GDNF receptor- $\beta$ & 1.76 & \\
\hline AF039203UTR\#1_at & Corticotropin-releasing factor type 1 receptor & 1.55 & \\
\hline X17012mRNA_s_at & IGFII gene for insulin-like growth factor II & & -1.73 \\
\hline \multicolumn{4}{|l|}{ Growth-related proteins } \\
\hline L21192_at & GAP-43 & 2.59 & \\
\hline rc_AA946313_s_at & Secreted acidic cystein-rich glycoprotein (osteonectin) & & -1.40 \\
\hline \multicolumn{4}{|l|}{ Immunological proteins } \\
\hline X62322_g_at & Granulin & -1.39 & \\
\hline M15562_g_at & MHC class II RT1.u-D- $\alpha$ chain & -1.40 & \\
\hline X71127_g_at & Complement component 1 , q subcomponent, $\beta$ polypeptide & -1.50 & \\
\hline X13044_at & $\begin{array}{l}\text { CD74 antigen (invariant polypeptide of major histocompatibility class II } \\
\text { antigen-associated) }\end{array}$ & -1.51 & -1.36 \\
\hline X61381cds_s_at & Interferon & -1.62 & \\
\hline rc_AA892775_at & Lysozyme & -1.69 & \\
\hline X56596_at & MHC class II antigen RT1.B-1 $\beta$-chain & -1.92 & \\
\hline M34253_g_at & Interferon regulatory factor 1 & -3.99 & \\
\hline rc_AA799861_at & Interferon regulatory factor 7 & -5.17 & \\
\hline U42719_at & C4 complement protein & & -1.42 \\
\hline
\end{tabular}




\begin{tabular}{|c|c|c|c|}
\hline Probe set & Gene & $\begin{array}{l}\text { Fold change } \\
1 \text { week }\end{array}$ & $\begin{array}{l}\text { Fold change } \\
4 \text { weeks }\end{array}$ \\
\hline \multicolumn{4}{|l|}{ Intracellular cell signaling } \\
\hline rc_AA892553_at & STAT1 & 3.23 & \\
\hline X955286 & Semaphorin III/collapsin-1 & 2.97 & \\
\hline D14425_s_at & Calcineurin B & 1.87 & \\
\hline M24104_g_at & VAMP-1 (synaptobrevin 2) & 1.58 & \\
\hline rc_AA894317_s_at & Chimerin 1 & 1.49 & \\
\hline AB003991_at & SNAP-25A & 1.47 & \\
\hline M31178_at & Calbindin D28 & 1.44 & \\
\hline U39875_at & Calcium binding protein $\mathrm{P} 22$ & 1.43 & \\
\hline AF009603_at & SH3p4 & 1.41 & \\
\hline M83676_at & RAB12, member RAS oncogene family & 1.38 & \\
\hline X91810_at & STAT3 & 1.25 & \\
\hline U90312_at & Synaptojanin II & -1.48 & \\
\hline rc_H31839_at & $\mathrm{bak} / \mathrm{bcl} 2$ antagonist & -1.91 & \\
\hline L333869_at & Ceruloplasmin (ferroxidase) & -1.96 & \\
\hline rc_AI176658_s_at & HSP27 & -2.23 & \\
\hline rc_AI102562_at & Metallothionein 1 & -4.56 & \\
\hline X17053mRNA_s_at & Immediate-early serum-responsive JE gene & -5.61 & \\
\hline AB012234_at & NF1-X1 & & -1.37 \\
\hline \multicolumn{4}{|l|}{ Ion transport } \\
\hline AF086758_g_at & $\mathrm{Na}-\mathrm{K}-2 \mathrm{Cl}$ cotransporter $(\mathrm{Nkcc} 1)$ & 7.83 & \\
\hline U14007_at & Aquaporin 4 & 3.19 & \\
\hline D90048exon_g_at & $\mathrm{Na}^{+}, \mathrm{K}+-\mathrm{ATPase}$ & 2.50 & -1.54 \\
\hline U28975mRNA\#2_g_at & Glycine transporter (GLYT-1) & 2.41 & \\
\hline U27558_at & Brain-specific inwardly rectifying $\mathrm{K}+$ channel 1 & 2.38 & \\
\hline AF004017_at & Electrogenic $\mathrm{Na}^{+}$bicarbonate cotransporter (NBC) & 1.87 & \\
\hline S75687_s_at & Glutamate/aspartate transporter & 1.65 & \\
\hline AF021923_at & Potassium-dependent sodium-calcium exchanger (NCKX2) & 1.63 & \\
\hline M26161_at & Potassium channel protein & -1.41 & \\
\hline X83585cds_s_at & Inward rectifier 10 & & -1.71 \\
\hline \multicolumn{4}{|l|}{ Myelin proteins } \\
\hline D28110_g_at & Myelin-associated/oligodendrocytic basic protein- 81 & 1.40 & \\
\hline \multicolumn{4}{|l|}{ Schwann cell proteins } \\
\hline Z29649_at & Periaxin & 1.80 & \\
\hline \multicolumn{4}{|l|}{ Diverse } \\
\hline rc_AI169327_g_at & TIMP1 (tissue inhibitor of metalloproteinase) & 3.37 & \\
\hline L18889 at & Calnexin & 1.41 & \\
\hline rc_AI012275_at & tpo1-developmentally regulated protein in oligo & 1.37 & \\
\hline rc_AA799494_at & Hypothetical protein & 1.33 & \\
\hline rc_AA892123_at & Ribosomal protein L36 & -1.35 & \\
\hline rc_AA893869_g_at & Hypothetical protein & -1.56 & \\
\hline AF 065438 at ${ }^{-\infty}$ & Mama mRNA & -1.88 & \\
\hline rc_AI639117_s_at & Kallikrein & -3.14 & \\
\hline U17035_s_at & mob-1 & -6.79 & \\
\hline Y07704_at & Hypothetical protein & -10.24 & \\
\hline $\mathrm{X} 05472 \mathrm{cds} \# 2$ at & $2.4 \mathrm{~kb}$ repeat DNA right terminal region & & -1.68 \\
\hline
\end{tabular}

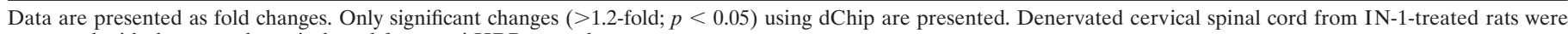
compared with denervated cervical cord from anti-HRP-treated rats.

1998). Here we show a time course of the initial, more random (sensory vs motor territories), sprouting followed by retraction and compensatory anatomical reorganization that respects the previously described topographic organization. Fiber growth most probably evolved from more random to more precise and topographically organized patterns, in addition to being attracted by the denervated targets. Thus, sensory fibers normally projecting into the dorsal horn grew across the midline to specifically reinnervate the denervated dorsal horn, and motor fibers sprouted across the midline to reinnervate the denervated ventral horn. Some of the sensory fibers were lost between 2 and 6 weeks, but the motor fibers were fully retained and elaborated their arbors. Surprisingly, we observed that the control anti-HRP antibody could also trigger a slight and transient sprouting of fibers in some conditions. This is likely to be attributable to the hybridoma grafts. However, even if we cannot dismiss this nonspecific 


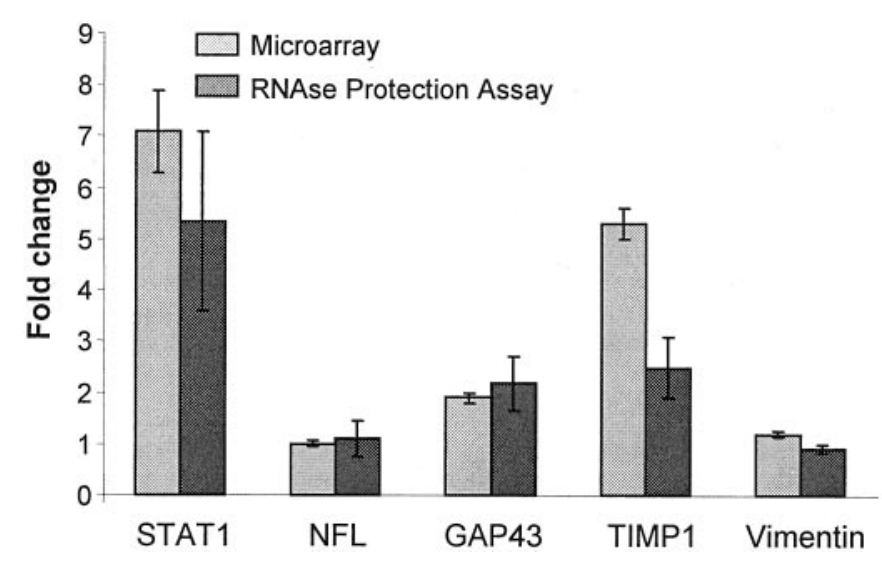

Figure 7. Results from RNase protection assays done on cervical spinal cord tissue and compared with results from the analysis with the Affymetrix gene chip. Five different genes were similarly expressed using both assays in rats treated with mAb IN-1 for $7 \mathrm{~d}$ compared with rats treated with an anti-HRP antibody.

component, the virulence of the anti-HRP-secreting cells was higher than that of IN-1 hybridomas, emphasizing the specificity of the IN-1-mediated sprouting. Moreover, even if anti-HRP treatment was able to induce sprouting of unlesioned fibers, it has never been reported that it could increase long-distance regeneration of lesioned fibers. This underscores the specificity of IN-1 in inhibiting Nogo-A and allowing the environment to be more permissive for axonal growth.

The presence of specific molecular cues appearing in the spinal cord as a consequence of the denervation was fully confirmed by the Affymetrix gene chip analysis. In addition to growth-related proteins (GAP-43), growth factors (BDNF, VEGF), and transcription factors (STATs) that were upregulated after IN-1 treatment alone, guidance molecules from the semaphorin (3 and 6) and slit family, additional growth factors and receptors (IGFs, BMPs, GDNF receptor) were upregulated after a pyramidotomy. As reflected by the gene expression pattern after combined pyramidotomy and IN-1 cell implantation, it seems likely that two mechanisms must be present for a meaningful compensatory reorganization of CST fibers across the midline of the spinal cord: the more general growth promoting effects of the IN-1 antibody and the denervation-induced modulation of guidance molecules and growth factors that allow fibers to reinnervate denervated target in an organized manner. In this plasticity model, the appearance of target-specific guidance information generated by the lesion seems to channel sprouting axons to reinnervate denervated targets as previously reported in regeneration studies (Wizenmann et al., 1993).

In conclusion, we demonstrated the clear endogenous sprouting effect of IN-1 antibody that, in combination with a unilateral lesion of the pyramids, greatly enhances the compensative capacity of adult motor CST fibers to reorganize in a target-specific

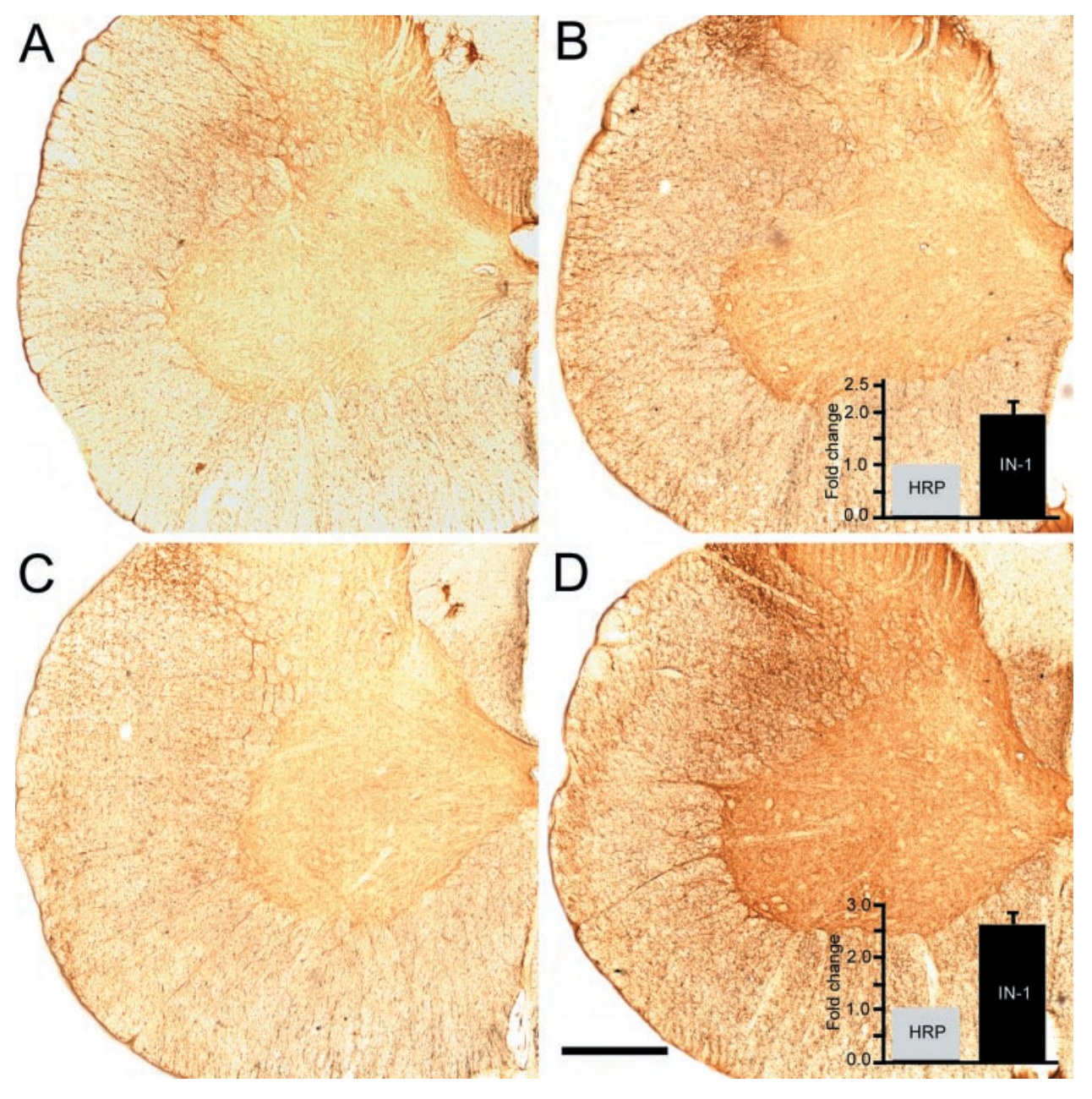

Figure 8. Photomicrographs of GAP-43 immunoreactivity in the denervated cervical spinal cord. IN-1 antibody treatment $(B)$ increased GAP-43 immunoreactivity (twofold by densitometry) in unlesioned animals when compared with unlesioned animals treated with anti-HRP antibody $(A)$. GAP-43 immunoreactivity was also increased (2.5-fold) 2 weeks after pyramidotomy and IN-1 antibody treatment $(D)$ compared with lesioned anti-HRP antibodytreated rats $(C)$. Scale bar, $850 \mu \mathrm{m}$. 
manner. Such processes will be of importance for long-term functional recovery after CNS lesion.

\section{REFERENCES}

Armand J (1982) The origin, course and terminations of corticospinal fibers in various mammals. Prog Brain Res 57:329-360.

Bernstein DR, Stelzner DJ (1983) Plasticity of the corticospinal tract following midthoracic spinal injury in the postnatal rat. J Comp Neurol 221:382-400.

Bregman BS, Kunkel-Bagden E, McAtee M, O’Neill A (1989) Extension of the critical period for developmental plasticity of the corticospinal pathway. J Comp Neurol 282:355-370.

Brosamle C, Schwab ME (1997) Cells of origin, course, and termination patterns of the ventral, uncrossed component of the mature rat corticospinal tract. J Comp Neurol 386:293-303.

Brosamle C, Huber AB, Fiedler M, Skerra A, Schwab ME (2000) Regeneration of lesioned corticospinal tract fibers in the adult rat induced by a recombinant, humanized IN-1 antibody fragment. J Neurosci 20:8061-8068.

Buffo A, Zagrebelsky M, Huber AB, Skerra A, Schwab ME, Strata P, Rossi F (2000) Application of neutralizing antibodies against NI-35/ 250 myelin-associated neurite growth inhibitory proteins to the adult rat cerebellum induces sprouting of uninjured Purkinje cell axons. J Neurosci 20:2275-2286.

Caroni P, Schwab ME (1988a) Antibody against myelin-associated inhibitor of neurite growth neutralizes nonpermissive substrate properties of CNS white matter. Neuron 1:85-96.

Caroni P, Schwab ME (1988b) Two membrane protein fractions from rat central myelin with inhibitory properties for neurite growth and fibroblast spreading. J Cell Biol 106:1281-1288.

Casale EJ, Light AR, Rustioni A (1988) Direct projection of the corticospinal tract to the superficial laminae of the spinal cord in the rat. J Comp Neurol 278:275-286.

Cheema SS, Rustioni A, Whitsel BL (1984) Light and electron microscopic evidence for a direct corticospinal projection to superficial laminae of the dorsal horn in cats and monkeys. J Comp Neurol 225:276-290

Chen MS, Huber AB, van der Haar ME, Frank M, Schnell L, Spillmann AA, Christ F, Schwab ME (2000) Nogo-A is a myelin-associated neurite outgrowth inhibitor and an antigen for monoclonal antibody IN-1. Nature 403:434-439.

Coulter JD, Jones EG (1977) Differential distribution of corticospinal projections from individual cytoarchitectonic fields in the monkey. Brain Res 129:335-340.

Donoghue JP, Wise SP (1982) The motor cortex of the rat: cytoarchitecture and microstimulation mapping. J Comp Neurol 212:76-88.

Fetz EE (1968) Pyramidal tract effects on interneurons in the cat lumbar dorsal horn. J Neurophysiol 31:69-80.

Herzog A, Brosamle C (1997) "Semifree-floating" treatment: a simple and fast method to process consecutive sections for immunohistochemistry and neuronal tracing. J Neurosci Methods 72:57-63.

Hicks SP, D'Amato CJ (1970) Motor-sensory and visual behavior after hemispherectomy in newborn and mature rats. Exp Neurol 29: $416-438$

Jones EG, Schreyer DJ, Wise SP (1982) Growth and maturation of the rat corticospinal tract. Prog Brain Res 57:361-379.

Joosten EA, Schuitman RL, Vermelis ME, Dederen PJ (1992) Postnatal development of the ipsilateral corticospinal component in rat spinal cord: a light and electron microscopic anterograde HRP study. J Comp Neurol 326:133-146.

Kalil K, Reh T (1979) Regrowth of severed axons in the neonatal central nervous system: establishment of normal connections. Science 205:1158-1161.

Kalil K, Reh T (1982) A light and electron microscopic study of regrowing pyramidal tract fibers. J Comp Neurol 211:265-275.

Kapfhammer JP, Schwab ME (1994a) Increased expression of the growth-associated protein GAP-43 in the myelin-free rat spinal cord. Eur J Neurosci 6:403-411.

Kapfhammer JP, Schwab ME (1994b) Inverse patterns of myelination and GAP-43 expression in the adult CNS: neurite growth inhibitors as regulators of neuronal plasticity? J Comp Neurol 340:194-206.

Klein RL, McNamara RK, King MA, Lenox RH, Muzyczka N, Meyer EM (1999) Generation of aberrant sprouting in the adult rat brain by GAP-43 somatic gene transfer. Brain Res 832:136-144.

Kuang RZ, Kalil K (1990) Branching patterns of corticospinal axon arbors in the rodent. J Comp Neurol 292:585-598.

Li C, Wong WH (2001) Model-based analysis of oligonucleotide arrays: expression index computation and outlier detection. Proc Natl Acad Sci USA 98:31-36.

Liu Y, Rouiller EM (1999) Mechanisms of recovery of dexterity following unilateral lesion of the sensorimotor cortex in adult monkeys. Exp Brain Res 128:149-159.
Merline M, Kalil K (1990) Cell death of corticospinal neurons is induced by axotomy before but not after innervation of spinal targets. J Comp Neurol 296:506-516.

Neafsey EJ, Bold EL, Haas G, Hurley-Gius KM, Quirk G, Sievert CF, Terreberry RR (1986) The organization of the rat motor cortex: a microstimulation mapping study. Brain Res 396:77-96.

O'Leary DD, Koester SE (1993) Development of projection neuron types, axon pathways, and patterned connections of the mammalian cortex. Neuron 10:991-1006.

Raineteau O, Z'Graggen WJ, Thallmair M, Schwab ME (1999) Sprouting and regeneration after pyramidotomy and blockade of the myelinassociated neurite growth inhibitors NI 35/250 in adult rats. Eur J Neurosci 11:1486-1490.

Raineteau O, Fouad K, Noth P, Thallmair M, Schwab ME (2001) Functional switch between motor tracts in the presence of the mAb IN-1 in the adult rat. Proc Natl Acad Sci USA 98:6929-6934.

Rajan P, Stewart CL, Fink JS (1995) LIF-mediated activation of STAT proteins after neuronal injury in vivo. NeuroReport 6:2240-2244.

Ralston DD, Ralston HJ, 3rd (1985) The terminations of corticospinal tract axons in the macaque monkey. J Comp Neurol 242:325-337.

Reh T, Kalil K (1981) Development of the pyramidal tract in the hamster. I. A light microscopic study. J Comp Neurol 200:55-67.

Schnell L, Schwab ME (1990) Axonal regeneration in the rat spinal cord produced by an antibody against myelin-associated neurite growth inhibitors. Nature 343:269-272.

Schnell L, Schwab ME (1993) Sprouting and regeneration of lesioned corticospinal tract fibres in the adult rat spinal cord. Eur J Neurosci 5:1156-1171

Schreyer DJ, Jones EG (1982) Growth and target finding by axons of the corticospinal tract in prenatal and postnatal rats. Neuroscience 7:1837-1853.

Schreyer DJ, Jones EG (1983) Growing corticospinal axons by-pass lesions of neonatal rat spinal cord. Neuroscience 9:31-40.

Schwab ME, Bartholdi D (1996) Degeneration and regeneration of axons in the lesioned spinal cord. Physiol Rev 76:319-370.

Schwaiger FW, Schmitt GH, Horvat A, Hager G, Streif R, Spitzer C, Gamal S, Breuer S, Brook GA, Nacimiento W, Kreutzberg GW (2000) Peripheral but not central axotomy induces changes in Janus kinases (JAK) and signal transducers and activators of transcription (STAT). Eur J Neurosci 12:1165-1176.

Spillmann AA, Bandtlow CE, Lottspeich F, Keller F, Schwab ME (1998) Identification and characterization of a bovine neurite growth inhibitor (bNI-220). J Biol Chem 273:19283-19293.

Steeves JD, Keirstead HS, Ethell DW, Hasan SJ, Muir GD, Pataky DM, McBride CB, Petrausch B, Zwimpfer TJ (1994) Permissive and restrictive periods for brainstem-spinal regeneration in the chick. Prog Brain Res 103:243-262.

Thallmair M, Metz GA, Z'Graggen WJ, Raineteau O, Kartje GL, Schwab ME (1998) Neurite growth inhibitors restrict plasticity and functional recovery following corticospinal tract lesions. Nat Neurosci 1:124-131.

Weibel D, Cadelli D, Schwab ME (1994) Regeneration of lesioned rat optic nerve fibers is improved after neutralization of myelin-associated neurite growth inhibitors. Brain Res 642:259-266.

Weidner N, Ner A, Salimi N, Tuszynski MH (2001) Spontaneous corticospinal axonal plasticity and functional recovery after adult central nervous system injury. Proc Natl Acad Sci USA 98:3513-3518

Whishaw IQ, Kolb B (1988) Sparing of skilled forelimb reaching and corticospinal projections after neonatal motor cortex removal or hemidecortication in the rat: support for the Kennard doctrine. Brain Res 451:97-114.

Wise SP, Donoghue JP (1986) Motor cortex of rodents. In: Cortex: sensory-motor areas and aspects of cortical connectivity (Jones EG, Peters A), pp 243-276. Boston: Kluwer.

Wizenmann A, Thies E, Klostermann S, Bonhoeffer F, Bahr M (1993) Appearance of target-specific guidance information for regenerating axons after CNS lesions. Neuron 11:975-983.

Yao GL, Kato H, Khalil M, Kiryu S, Kiyama H (1997) Selective upregulation of cytokine receptor subchain and their intracellular signalling molecules after peripheral nerve injury. Eur J Neurosci 9: $1047-1054$

Zagrebelsky M, Buffo A, Skerra A, Schwab ME, Strata P, Rossi F (1998) Retrograde regulation of growth-associated gene expression in adult rat Purkinje cells by myelin-associated neurite growth inhibitory proteins. J Neurosci 18:7912-7929.

Z'Graggen WJ, Metz GA, Kartje GL, Thallmair M, Schwab ME (1998) Functional recovery and enhanced corticofugal plasticity after unilateral pyramidal tract lesion and blockade of myelin-associated neurite growth inhibitors in adult rats. J Neurosci 18:4744-4757.

Z'Graggen WJ, Fouad K, Raineteau O, Metz GA, Schwab ME, Kartje GL (2000) Compensatory sprouting and impulse rerouting after unilateral pyramidal tract lesion in neonatal rats. J Neurosci 20 : 6561-6569. 